\title{
Van Galen's memorandum on the Alor Islands in 1946. An annotated translation with an introduction. Part 2.
}

\section{Edited and translated by Hans Hägerdal}

The present study consists of a translation of the second part of the Memorie van Overgave van den fundgeerend Controleur van Alor, G.A.M. van Galen, together with annotations. The translation of the first part of this text was published in HumaNetten 25/2010, pages 14-44. The Dutch original is to be found in 'Collectie Losse Aanwinsten Bestuursambtenaren’ No. 26, Nationaal Archief, The Hague.

As pointed out in the introduction to the first part of the translation, the Alor Islands in eastern Indonesia are highly interesting from an anthropological, ethnographical, linguistic and historical point of view. On these islands, the Austronesian and Papuan language families meet, and so do various cultural forms and influences. At the same time, the relative remoteness of the islands from the traditional centres of civilization in the Archipelago has ensured the preservation of cultural specifics which have been studied by avid foreign researchers.

While the colonial official G.A.M. van Galen was not a researcher as such, he was a perceptive observer of life on Alor in the wake of World War II. In this part of the text he provides us with numerous details about the local Alorese adat, the traditional body of customs and regulations that guided the flow of life on these islands. He pays much attention to the ways in which harvest feasts, marriages and burials were conducted, and notes the importance of the bronze drums, the famous moko. His view of the character of the local population is probably no more prejudiced than could be expected from an educated European official in the 1940s. In his opinion the Alorese stand out as merry, carefree and somewhat lazy people, but not necessarily unintelligent or unfit for modern development. The contrast to his predecessor K. Rijnders, whose Memorie he quotes under the heading 'Political situation', is apparent.

The Memorie of Van Galen furthermore deals with various issues of the colonial state, which tried to introduce education and health care on the remote islands although with mixed success. We also learn how intellectual currents emanating from the central parts of the Indonesian colony eventually reached the small world of Alor. Van Galen notes with some consternation how Islamic and nationalist groups establish a toehold on the islands, at a time when the Indonesian revolution is in full swing on Java.

Finally, two brief appended reports cast important light on conditions during the harsh rule of the Japanese in 1942-45. An interesting point in these reports is that they indicate how the system of zelfbesturende landschappen (self-ruling territories) that the Dutch had constructed after 1910 broke down as soon as the pemerintahan, the colonial government, was gone. The Dutchmen hurriedly left Alor after a mutiny among the local 


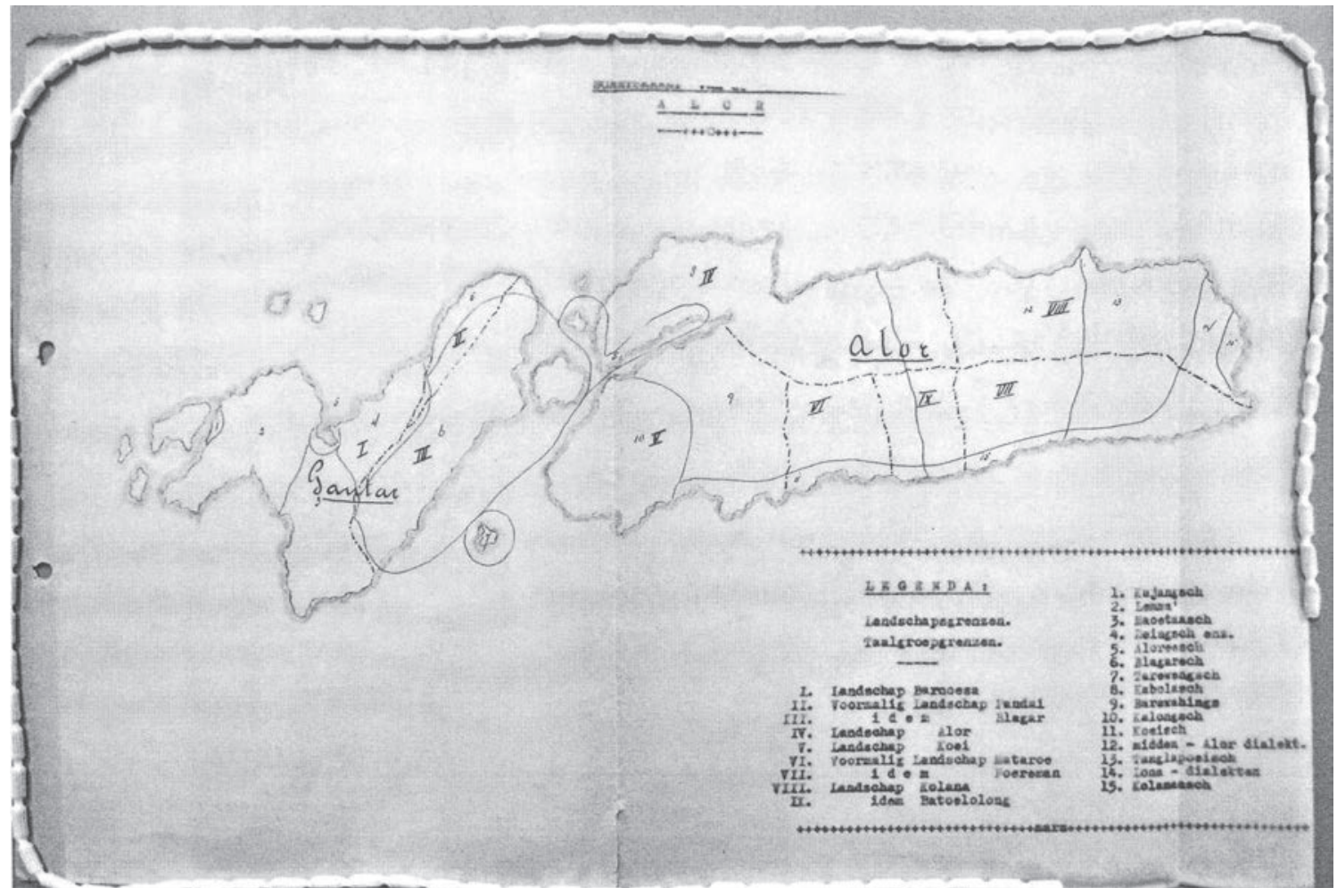

Map of Alor and Pantar.

troops in 1942, at the same time as the Japanese onslaught reached eastern Indonesia. As it turned out the mountain people flatly refused to obey the coastal rajas whom they regarded as covetous and intrusive. It was only by stern measures, and with some ensuing atrocities, by Japanese troops that order was restored on the islands. The infamous system of conscript labourers, romushas, also had its consequences on remote places like Alor. Many Alorese were forced to toil on roads and military installations on Timor under poor conditions.

At the moment when Van Galen lay down his pen in December 1946, the Dutch colonial government had three more years to go. Nine days after the conclusion of the Memorie, on the Christmas Eve of 1946, the colonial authorities tried to better their chances of maintaining authority in the Archipelago by establishing a pseudo-state, East Indonesia or Negara Indonesia Timur. It was an enormous area that encompassed the islands from Bali to the Aru Archipelago, and thus included the Alor Islands. The part where the Alor Islands are situated was among the less turbulent during a revolution that otherwise cost perhaps 100,000 lives across the Archipelago. In spite of some nationalist agitation, the simmering discontent never resulted in extensive fighting in the Timor area. But the end of the colonial era inevitably drew towards its end. On 27 December 1949 the Netherlands formally transferred sovereignty over its old colonial domains to the government of the nationalist leader Sukarno. While East Indonesia was at first a part of a federal Indonesian state, this was not satisfactory to the nationalists. ${ }^{1}$ In August 1950 a unitary state was established, a state that would soon alter colonial as well as traditional governance on Alor. ${ }^{2}$

1 Cribb \& Brown 1995, pp. 32-8.

2 Widiyatmika 2007, pp. 395-404. 


\title{
Memorie van Overgave van den fundgeerend Controleur van Alor G.A.M. van Galen
}

\author{
Dated 15 December 1946. \\ Collectie Losse Aanwinsten Bestuursambtenaren No. 26, \\ Nationaal Archief, Den Haag
}

Part 2

\section{CHARACTER AND CUSTOMS OF THE POPULATION}

In general, the characteristics of the population on these islands are: cheerful, merrily boisterous, quick to celebrate, carefree and a bit lazy.

Among them one meets the most diverging types and customs, which is not surprising considering the mixture with other races and the previous isolation. The mountain people of the peninsula, who are less primitive than the other parts of the population, due to more contact with the Kalabahi post, are usually clad in sarong, while the more wellto-do there carry a shirt. The women likewise walk about in sarong. At least the younger generation is already used to wear white (!) bajaus. ${ }^{3}$

Through the large number of schools in this part, most of the people are able to speak Malay. Furthermore, they are not stupid. As everywhere, the woman carries out most of the work, while the man is content to assist with planting once a year, carry out corvée labour, and for the rest keep guard.

The population in the rest of Alor, especially in the landschap Kui and the communities Welai and Limbur, are still utterly primitive. Most of them, women as well as men, are clad in a loincloth, while the men, who are usually well built, wear their hair quite long and hold it together by wrapping it with a pinang ${ }^{4}$ leaf, and wreath it with metres of red woven rottan.

Such types, the more if they are clad in warrior attire, which consists of a broad girdle where arrows are tucked in a fan-shape and a shield of joint kerbau ${ }^{5}$ hides plus arrow and bow in the hand, indeed make a wild impression, and formed the attraction for those several Americans who formerly came to watch the "wild and woolly people" of Alor. To the most beloved popular amusements belongs the "lego-lego". Any pretext is used to arrange these dances, which begin after sunset and end by sunrise.

Each kampong also has its own lego-lego place, consisting of a flat piece of terrain, in the middle of which a pile of stones has been erected, about 1 meter high. In the middle of this there is an erect stone. In former times, the heads of slain adversaries were placed on this pile of stones, after which the entire kampong performed the war dance around it.

The lego-lego is a row dance, and is performed in various ways in the various parts of the residency. The dances can be distinguished in those where:

3 Or baju, jacket or shirt.

4 Betel leaf. According to other sources, as Cora Du Bois (1944) and Ruth Barnes (2004), it would rather have been an areca bark hair cylinder (foefak).

5 Buffalo. 
1. The men and women stand in one circle.

2. The women in an inner circle, and the men form an outer circle.

3. Music (!) from gongs, mokos and drums is performed.

4. Singing is only by individual pantun ${ }^{6}$ singers in the middle of the circle.

5. The entire horde roars a pantun in an irregular way, one after another, in groups of 5 or 6 men while jumping in a circle that moves to the right.

One also distinguishes between war dances and amusement dances. The war dances that one can often see in the mountainous areas of southern Alor, are performed in full armament, whereby they make wild jumps and stamp the ground while holding the elbow of the next with the left hand and sing (!) some song about old fights.

The men as well as the women and children take part in the amusement dances. At these dances, one or more pantun singers who are mostly elderly people jump in the middle of the circle and sing the actual words of the song, whereupon the other participants sing along in the refrain.

One can understand that these dances, also since they are performed by the sparse light of a wooden fire, are often used for love relations and not always to bond "free" women. In Kolana the intention of a couple to marry is often announced at a lego-lego place. This happens as follows:

If a young man is interested in a girl, he asks during the dance for some sirih or tobacco from her sirih basket that only unmarried women carry on their head. If the man in question is to the young girl's taste, she then asks him for some sirih in return but immediately takes the entire basket that hangs by the hair at the back, as a token of acquiescence. The other participants at the ball - and at a lego-lego that is virtually the entire kampong - then see that the two of them are in agreement. It is thus a kind of public announcement of their betrothal.

Before each lego-lego, and the more if it is held in honour of the visit of an official, a grand toilette is made, which means that each one puts on a string or band of corals or other adornments, while feather plumes or bands are placed in the hair.

On Pantar - and the custom is also mentioned in other areas - the women at such occasions carry copper bangles around their legs, which cover the legs from the ankle to the calf. Meanwhile the men are adorned with red-white-blue girdles around their waist and white plumes decorated with bands in the hair. Through the "show" before the Americans, all kinds of other adornments have slowly been added, which are however not original.

\section{Marriage and what comes with it, according to the adat in Dulolong.}

Marriage can take place in two ways, namely:

1. With the consent of the families of each, and

2. Through a "bawa lari” marriage.

6 Pantun refers to a sort of traditional poetry.

7 Bawa lari, run away with someone. 
Concerning 1. If a young man is interested in a girl, he sends one of his family members to her to ask for sirih pinang. If the girl is inclined to become his spouse, she gives him what is asked for, and if not, she sends the messenger back empty-handed. She announces what has occurred to her parents. Betrothal is, in the first case, then reckoned to have taken place, whereupon the bride-price is fixed.

Here one has to reckon with the "estate" to which the bride belongs, and, if it is the eldest daughter, how much belis ${ }^{8}$ has been paid for her mother. This belis varies between 1 moko makassar tanah worth 150 guilders plus 7 mokos worth 20 to 80 guilders for an ordinary kampong girl, to 1 moko olemalei worth 800 guilders and 15 mokos and gongs for anyone who marries a girl from a raja family. This belis is paid by the father or more correctly the family of the bridegroom, to that of the bride. Nevertheless, the latter gives a so called "balasan" at the value of half the bride-price.

Concerning 2. If the young man and the girl for some reason, mostly because the man in question does not possess enough mokos, do not want to await the consent of their parents before entering marriage, the girl escapes with him to his dwelling. This cannot be kept hidden for long before the parents of the family of the girl go to the family of the abductor and ask for the belis. If they can not deliver the requested bride-price, then the family of the bride has the right to bring the couple to their house and keep them there until the father of the family of the bridegroom has completed the belis. Only then can the couple choose their living place.

If the young man has already had intercourse with the girl and this is discovered, then things are handled as under no. 2 in case it leads to marriage. If not, the man pays a tutup malu ${ }^{10}$ of 1 moko worth 30 guilders and 4 mokos worth 15 guilders each for the girl. (These prices are valid for an ordinary kampong girl; for girls of higher standing correspondingly higher "tutup malu" applies.) After all the regulations regarding the bride-price and balasan have been made and a number of cattle and food have been collected for the marriage feast, the day for the marriage is fixed.

On this day, after having enjoyed what is necessary at the feast meal, the entire families of the bridegroom and the bride lead the "victim" to the house of the bride where they are united in marriage. Not long after, the belis and the balasan is completed by the two parties. After 5 days of feasting and other amusements, the young couple is brought to the home of the husband where they are to remain. If someone marries a widow, he pays a $k a i n^{11}$ and a gong to the family of the deceased husband. However, the children of the first marriage go to the family of the $1^{\text {st }}$ husband. ${ }^{12}$ If he pays back the entire belis to the family of the deceased husband, he obtains the children from the first marriage.

\footnotetext{
8 Bride-price.

9 Response, retaliation, counter payment.

10 Literally, covering the shame.

11 A cloth, especially of sarong type.

12 Van Galen uses numbers somewhat inconsequently: $1^{\text {st }}$ - first, etc. In this translation I generally follow his way of writing.
} 


\section{Divorce}

If one of the two spouses wishes to dissolve the marriage because of misbehaviour, insufficient care, etc. on the part of the other spouse, he [or she] goes to the one who concluded the marriage and asks for divorce. If the man asks for divorce, all the goods in the house go the woman and the other way around. Another case is when the husband has been cuckolded; if he wants to keep his wife, the guilty man pays a "tutup malu" to the husband. However, if he no longer wants to keep his woman as spouse, then the unfaithful is obliged to pay back the entire belis to him.

\section{Adat customs by the burials among the heathens of Kui}

If somebody passes away, certain watch men, no relatives of the deceased, keep watch by the body in the night before the burial. For this, each one receives a kain, as they say, to wipe off the tears that they must shed during the watch. In the following morning the grave is, under the supervision of an uncle of the deceased who is also entrusted the general management, dug by 5 men after they have marked out the place with 5 sticks. These 5 diggers each receive a sarong.

Until the actual funeral, one person stays behind in the burial pit, armed with a piece of wood in order to chase away possible spirits of the living who may have ended up in the grave. By the burial, the corpse, which is clad in a sarong, is carried by the uncle and the 4 diggers. At this point, no further relatives are present as they are afraid of the spirits. The following articles are donated to the dead: arrow and bow; a periuk ${ }^{13}$ with rice; 5 pieces of meat on 5 skewers of which 2 are already roasted and serve as food for the deceased on his way to the kampong of the dead, "Ek kik bok tik", while the 3 others are destined to be prepared by the dead himself on arrival in that place. Furthermore, sirih pinang, ${ }^{14}$ tobacco, a piece of chalk and a bamboo comb are all put in a basket and placed to the right of the body.

After the grave has been closed, the eldest man puts water in a piece of bamboo before the house. Only then the family comes out from their houses. Each one puts a couple of fingers in the water, rub them over their foreheads while uttering the words "E hirnang, E kalnang" (tida pemali lagi). ${ }^{15}$ On the following day the family puts rice, sirih pinang, meat and salt on the grave, uttering the words "Receive these goods and do not think more of us; go to your ancestors." After 5 days this procedure is repeated. The number 5 plays a great role at mortuary feasts and funerals, so great that this number is pemali for heathen people in ordinary life. Thus one never sees people buying 5 pieces of this or that at the pasar, but always 4 or 6 pieces.

\section{Adat customs at a mortuary feast in Batulolong}

If somebody has passed away, the uncle of the deceased comes inside the kampong with great alarm. He slaps people to the left and right and cries "Where is my child? Bring it here quickly". Only when the family of the dead brings him mokos and gongs does he

13 Caldron, cooking pot, in Alor made of clay.

14 Betel leaves and areca nuts; ingredients for betel chewing.

15 The Malay words, which do not seem to literally render the parallelism of the original expression, mean "no taboo/sacred stuff anymore." 
stop his raging. If the family has enough mokos and gongs to give as compensation to those helping at the funeral, the deceased is buried within a week. If not, these articles must first be gathered.

Until the burial takes place the spouse must keep watch by the deceased, if the latter has enjoyed such a belonging [i.e., a spouse]; otherwise others perform this watching duty. After the burial the family of the deceased once again gather mokos, gongs, cattle and food in order the give the necessary feasts. Thus feasts are given for:
a. The dead
b. The carriers of the corpse
c. The people who have brought sarongs with which the body is wrapped
d. The people who have made the soul perahu

As for the soul perahu the following applies.

According to belief, the souls of the dead go to Eibike (at the border between Batulolong and Kui). When a mortuary feast is held, a soul perahu is always made in order to provide a comfortable vehicle for the dead. When this perahu is constructed, various animals are slaughtered, whose blood is applied to the perahu. Thereby the soul of the deceased is called with the words: "Hal bapa (ibu, saudara) sekarang sudah sedia nasi dan daging, datanglah makan sepuas-puasnya". ${ }^{16}$ When the perahu is taken away from the kampong some bones from the slaughtered animals are placed in it, along with a few empty baskets for sirih pinang, chalk and tobacco. The perahu, accompanied by all those celebrating the feast, is brought away whereby the master of ceremonies has a lontar leaf tied to his arm, the other end of which is tied to the bones in the perahu.

As the soul perahu has come outside the kampong, the lontar leaf is cut by him with the words "Selamat berjalan, selamat bercerai, jangan ingat kami lagi, sebagaimana kini kami tidak ingat kamu lagi”. ${ }^{17}$

\section{The mortuary feast in Atimelang (Limbur)}

Concerning this, Mej. Nicolspeyer writes as follows.

The mortuary feasts consist of the following sequence of 8 feasts:

1. The fokung huore, the abangpilia, the nabuke, the baleihiede and the aneikule, which all take place on the first day.

The fokung huore is the beating on gongs that, together with the wailing of the women, immediately commences after the demise, and continues the entire day with short breaks. The family of the deceased goes to the male houses of him or her who has died, in order to receive the first gifts. This request for gifts is called abangpilia. At this occasion the foremost of the six male houses, the manufeng, bestows the burial clothing, and then the burial, the nabuke, takes place.

16 Concerning father (mother, sibling); the rice and meat is now prepared, come and eat to your satisfaction.

17 Lucky journey, lucky separation; do not further remember us; in the same manner we do not remember you any more. 
Members of the aforementioned namufeng [manufeng?] walk with the corpse, shrouded in the kain, towards the grave and throw it down there with a forceful hurl. Previously half the corpse was left above earth, but this is now forbidden by the government.

Chests, as prescribed by the missionaries, are still rarely used.

In the afternoon the beleihide ${ }^{18}$ takes place, the roasting of pisang, which are handed out to the guest, beginning with the members of the male houses. Afterwards rice and pork is handed out (tofangtode). Finally the male houses receive small gifts which are called aneikule.

2. Four days later the herberk $a^{19}$ takes place, the handing out of boiled meat and boiled rice.

3. Four days later again, a similar handing out of foodstuff takes place, which however is called the hekang. ${ }^{20}$

4. After some months there is once again a handing out of boiled meat and boiled rice, the herolik. ${ }^{21}$ On this occasion the male houses receive the gifts in return for their own gifts at the abangpilia.

5. A long time, sometimes more than a year afterwards, the baletne ${ }^{22}$ is celebrated, where small baskets of boiled rice are distributed.

6. Then follows the hekotoke, ${ }^{23}$ when raw meat and uncooked, stomped rice and maize are shared out.

7. The hekarfungbele or helungfabele ${ }^{24}$ are, respectively, the final feast for a male or a female deceased. In the first case a kerbau is bought, the meat of which is eaten although the bones are placed on a veranda, built from the wood of a particular tree and erected at the side of the house at the edge of the village. It is believed that the soul of the dead comes to fetch them there, and with these bones acquires the kerbau. At the helungfabele for a woman the same applies, but with a sheep.

8. The tilabele and the hekaraugbele constitute the last ceremonies. That is, respectively, the buying of the taboo string, the sacred string with which the dead must lead the kerbau (or the sheep) and which is provided by the male houses; and the buying of the flower-patterned kain, likewise provided by the male houses, of which a piece of kain is placed on the grave.

The latter feasts, number 7 and 8 , are seldom carried out since they carry with them too high costs. A kerbau, for example, is a "rara avis" in the mountain area and must be brought in with great costs. When a karfungbele takes place it is mostly a common feast for various families. In the same way, in one family most of the mortuary feasts are given for several deceased at the same time. For a child up to about 5 years, only one mortuary feast is given.

18 Balei $=$ pisang [banana]; hiede $=$ roasting [Van Galen's footnote.

19 Berka = simple; he = possessive suffix 3rd person singular [Van Galen's footnote].

20 Kang $=$ good [Van Galen's footnote].

21 Rolik = the foodstuff packaging [Van Galen's footnote].

22 Balet = woven package of rice (Mal. Ketupat); ne = to eat [Van Galen's footnote].

23 Kotok = raw [Van Galen's footnote].

$24 \mathrm{Bel}=$ to buy; karfung = kerbau; lungfa = sheep [Van Galen's footnote]. 
Apart from these brief accounts of mortuary feasts, I also acquired information on two other important feasts.

\section{The harvest feast in Atimelang}

At the harvest feast, known as the yetoke feast, a curious figure appears, the "ye adua" (in Malay, tuan air = lord of the water). This is a family profession that is inherited from father to son. The functionary must submit to a food taboo. That is, when the maize starts to grow, the ye adua is forbidden to eat it. When the maize is ripe and the yetoke feast can be held, the ye adua goes from the village to fetch holy water. During his absence all the people go into their houses and keep hidden. When the ye adua returns he first brings the holy water to his own house. There he cooks twenty unpeeled cobs of maize which he carries to the dancing place in two bowls (the dancing place of his own kin). He places the bowls on the dancing place stones (kameng). Then he calls all the inhabitants from their houses with the cry "aihaung!", takes some maize into his mouth and spits it out, whereby he announces that all the animals that are harmful for the fields, such as rats, cats and birds, have been spat out. The rest of the maize in the two bowls he throws away, and then pours out the holy water. Meanwhile the bystanders try to acquire some of the auspicious maize that has been thrown away. With this the first part of the harvest feast is concluded, people return home to prepare a meal, and for the ye adua the taboo against eating maize is abrogated.

Three days later the $b o l^{25}$ takes place whereby the men, hitting around with young bamboo branches with leaves, roam through the village while fires are lit everywhere and gongs and mokos are beaten. Another five days later food is cooked in a big bowl (ading). Every family count their deceased and make a very small ketupat ${ }^{26}$ of rice for each dead, which is hung above the grave.

\section{Inheritance law}

As is expected in an area with paternal rights, the women are practically excluded from inheritance. Through her marriage the woman is transferred to another family, and it would thus just be a loss to give her part of the inherited goods. She may only bring along her personal belongings, such as spinning and weaving equipment and such. Certainly, she retains a certain right to use the plot of her family. The inheritance goes to the eldest son as the new headman of the family, who as such controls the inherited goods. There is a duty here to maintain the younger family members and support them in the payment of the bride-wealth.

$25 \mathrm{Bol}=$ beat [Van Galen's footnote].

26 Rice cake which has been boiled in a packet made of young coconut leaves. 


\section{E. LANGUAGE}

In the Onderafdeeling Alor, with a population of about 90,000 souls, at least 13 different languages are spoken, each of them in turn divided into dialects. For the distribution of these languages, please refer to the appended outline map. ${ }^{27}$

The advantage of Malay as a general language of communication is even greater here than in other areas. The Malay language is, for mutual contact between various parts, almost a necessity. For the most part, the zelfbestuurders ${ }^{28}$ and even the kapitan $^{29} \mathrm{know}$ only a few of the languages that are spoken in their territory.

\section{F. EDUCATION}

Popular education is entirely in the hands of the Indian Church..$^{30}$ The Indian preacher living in Kalabahi is also headmaster of the school. As for the growth of this education the survey below provides an overview.

\begin{tabular}{lrrrrrrr} 
& $\begin{array}{r}\text { Number: } \\
\text { Schools }\end{array}$ & Teachers & \multicolumn{2}{c}{ Number of pupils: } & $\begin{array}{c}\text { Average number } \\
\text { of school visitors }\end{array}$ & Absent \\
& $27+5^{*}$ & 34 & 1640 & 449 & 2089 & & \\
end 1937 & $37+1^{*}$ & 47 & 2304 & 651 & 2960 & 2603 & $12 \%$ \\
end 1942 & 36 & 56 & 3217 & 1330 & 4217 & 3315 & $21 \%$ \\
end 1945 & 37 & 64 & 3771 & 1555 & 5326 & 4616 & $13 \%$ \\
3rd quarter 1946 & & & & & & &
\end{tabular}

One can observe a considerable increase. In about 10 years the number of learners has more than doubled. Also the number of girl learners has risen relatively in comparison with the boys. If they were $28 \%$ of the number of the boys in 1937 , they were $42 \%$ at the end of 1946. The percentage of absentees is however still high, and higher in the mountain areas than in the coastal areas. Comparative figures for the other areas in this residency ${ }^{31}$ are not available to me.

The desire for education, though being indeed present mainly in the coastal areas, must however be taken with a grain of salt. At the start of the new school year the authorities always require help to get a sufficient number of learners. To bring the learners back to school is also a matter that always demands the attention of the administration. Boarding [internaten] is associated with almost all the popular schools [volksscholen]. These stand under the supervision of the teacher. A boarding regulation has been fixed by the resident. The adoption of this regulation, however, still leaves much to be desired. One should strive to abolish this boarding where possible, due to the great troubles that are

27 Reproduced in part one of the translation, HumaNetten 2010.

28 Self-rulers; rajas under Dutch suzerainty.

29 Assistant or sub-ruler to the raja; from Portuguese capitão.

30 Indische Kerk, the best established missionary organization in colonial Indonesia that received state support. It was responsible for the Protestant mission in large parts of eastern Indonesia (Cribb 2000, p. 49).

31 That is, Timor en Onderhoorigheden. 
associated with this system, although the advantages such as winning the children for order and prudence, etc. are surely not negligible in this primitive society. This aim could be advanced through splitting schools where there are now two or three teaching positions, into one-man schools. Whether this is less desirable from an educational point of view I do not know.

The difficulty until now has been that good subsidies could be acquired via the hiring of a new teacher through the increase of the number of learners, rather than the establishment of a new school through division. When a similar issue is brought up by the headmaster of the school in the right way, the inspection shall surely be able to approve of it.

As for the issue of the double function of school teacher and guru agama ${ }^{32}$, a few things have already been noted above.

As a follow-up to the popular education, a continuation school [vervolgschool] has been established in Kalabahi. The aim is to open several continuation schools; I would suggest one continuation school for every 10 popular schools, where one would consider Kolana and Blangmerang on Pantar.

An extra class with Dutch as the language of communication will be added to the continuation school in Kalabahi, whenever a proper teacher can be found. It would be very important if one could quickly open the agriculture class that has been abrogated due to the death of the agriculture teacher Noenoehitoe. Further plans for the future are:

1. The opening up of a course for popular teachers by 1 August 1947 in order to redeem the great shortage of educators.

2. The opening up of a lower school [lagere school] in Kalabahi as soon as educators and school materials are present.

3. The opening up of a fourth class at the popular school in Kolana, Batulolong, Moru and Blangmerang by 1 August 1947.

\section{Courses for illiterate people}

In July-August in the preceding year, all over this Onderafdeeling, courses were established for illiterate people, and they are given by the popular teachers and utusan injil. ${ }^{33}$ Learners of these courses were mostly the older boys and girls from the catechism education, although also older people participated in these courses. These courses were held once a week after the end of the catechism lessons. The aim is to teach them to write and read, even if it only means that they can distinguish between the letters of the alphabet and write their names. Furthermore, to give them knowledge of Malay. ${ }^{34}$ At the beginning of the planting season, a lot of them will disappear, which does not need to be a great impediment to starting anew in the dry season.

32 Malay, religous teacher.

33 Messengers of the gospel.

34 It was, from a Dutch colonial point of view, impractical to teach Indonesian people Dutch in the first place. Malay was the standard means of communication in the Archipelago, which was later developed into Bahasa Indonesia. 
Of the useful effects of these courses, which are set up on the request of the zelfbestuurders of Alor and Kui, one should not have too high expectations. It deserves respect as an expression of the ambition of the zelfbestuurders and the more developed members to lift this retarded population up from their inertia and contribute to the development of these areas.

\section{G. ECONOMIC CONDITIONS}

\section{General remarks}

The main means of livelihood, surely in any case for the mountain people, is agriculture. Next to that, the collecting of forest products such as canari, kemiri, tamarinds, beeswax, and so on, is an important source of income, as one may gather from the figures for export and import. For the people of the coastal kampongs, such as the Mohammedan kampongs in the district Dulolong and on Pantar, and the large Christian kampong Kolana and the inhabitants of the islets Pura, Umapura and Ternate, actual agriculture is of less importance. Along the western coast of the Kabola Peninsula and the eastern and northern coasts of Pantar, one certainly encounters extensive kelapa plantations, which stood for about half of the total export before the war. For a large part, however, the coastal population lives off the incomes from weaving, which is done by the women. The woven kain and cawat ${ }^{35}$ are important objects of barter in order to obtain the necessary rice and maize. The mountain people do not understand the art of weaving with the exception of a few kampongs in the kapitan-ship Probur (Kui).

Fishing is another source of income, as well as the diving for mussels such as batulaga and lola. The incomes from fishing are nevertheless quite small, so that import of dried fish from the Solor Islands and Flores is necessary to fill the need.

Pottery is virtually restricted to the kampongs Lewalu and Lewolang along the Kabola Bay. These kampongs momentarily enjoy a golden age. The pottery, too, is exclusively handled by women.

The Alorese are devoted agriculturists. Two, three or four fields per family are normal. A significant advantage hereby is that the fields do not need to be surrounded by paggers $^{36}$ due to the lack of cattle. During normal harvest years there is also a significant surplus for export, especially maize, that is for a large part brought to Timor. Agriculture still consists almost entirely of ladang ${ }^{37}$ cultivation, and is still quite primitive. There is little working on the soil which is often unsuitable in this difficult mountain terrain. The construction of terraces by piling stones occurs in the kapitan-ship Mataru.

35 Loincloths.

36 Indo-Dutch, from Malay pagar, fence.

37 Dry agricultural field. 
As for the means of improving the agricultural methods, this is discussed below, in the account of the Agricultural Guidance Service. Below are some numbers for comparison concerning the import and export over the years 1935, 1936, 1937, 1941 and 1946.

\begin{tabular}{lrlr}
\multicolumn{2}{c}{ Export } & (guilders) & \multicolumn{2}{l}{ Import } & (guilders) \\
1935 & 58,361 & 1935 & 35,442 \\
1936 & 69,334 & 1936 & 40,235 \\
1937 & 98,688 & 1937 & 106,877 \\
1941 & 60,506 & 1941 & --- \\
1946 & 56,425 & 1946 & ca 105,741
\end{tabular}

The table below gives a survey of the items of export in 1941 and $1946 .^{38}$

$\begin{array}{lrrrrrrrrrr}\text { Export } & 1938 & & 1939 & & 1940 & & 1941 & & 1946 & \\ \text { [Amount-kg, } & \text { Am. } & \text { Value } & \text { Am. } & \text { Value } & \text { Am. } & \text { Value } & \text { Am. } & \text { Value } & \text { Am. } & \text { Value } \\ \text { Value - f] } & & & & & & & & & & \\ \text { Copra } & 428167 & 31150 & 405738 & 19559 & 113235 & 6018 & 278164 & 8505 & 300 & 30 \\ \text { Hides and } & 1141 & 844 & 401 & 394 & 1026 & 651 & 891 & 425 & 0 & 0 \\ \text { birds } & & & & & & & & & & \\ \text { Deer horns } & 826 & 204 & 1214 & 313 & 904 & 239 & 314 & 110 & 624 & 93.60 \\ \text { Kemiri } & 118965 & 17064 & 98664 & 7152 & 112123 & 7982 & 149543 & 10035 & 41966 & 4673.95 \\ \text { Canari } & 15159 & 1050 & 16444 & 1734 & 29871 & 3060 & 51840 & 5166 & 1755 & 1203.95 \\ \text { Kacang iju } & 166 & 12 & 4495 & 315 & 3265 & 231 & 8741 & 623 & 64 & 25.60 \\ \text { Kajang mats } & 80 & 8 & 0 & 0 & 180 & 15 & 1130 & 79 & 148 & 149 \\ \text { Peeled rice } & 106378 & 7955 & 45363 & 3273 & 83398 & 5504 & 14050 & 1258 & 0 & 0 \\ \text { Shells } & 1526 & 343 & 5017 & 1304 & 4008 & 778 & 2171 & 518 & 6071 & 1807.95 \\ \text { Sirih hutan } & 916 & 53 & 4469 & 245 & 2109 & 113 & 2621 & 133 & 40 & 10 \\ \text { Tamarinds } & 122329 & 3953 & 68322 & 2708 & 230428 & 10332 & 279990 & 9248 & 126462 & 21369.95 \\ \text { Maize } & 424166 & 13120 & 241912 & 7917 & 218067 & 6828 & 159884 & 5508 & 7150 & 1072.50 \\ \text { Pinang nuts } & 32413 & 2437 & 9386 & 694 & 14687 & 786 & 10083 & 507 & 14055 & 10334.95 \\ \text { Birds nests } & 6 & 39 & 23 & 98 & 5 & 28 & 27 & 172 & 75 & 62.50 \\ \text { Beeswax } & 278 & 224 & 1547 & 1239 & 3354 & 2297 & 18864 & 13447 & 1280 & 1435 \\ \text { Kulit loba } & 1051 & 55 & 1539 & 72 & 1721 & 67 & 1300 & 57 & 750 & 329.20 \\ \text { Biji jarak } & 4070 & 344 & 5729 & 484 & 8410 & 676 & 23212 & 1340 & 0 & 0 \\ \text { Kulit soga } & 0 & 0 & 0 & 0 & 0 & 0 & 217282 & 3375 & 0 & 0 \\ \text { Tobacco } & 0 & 0 & 0 & 0 & 0 & 0 & 0 & 0 & 640 & 2560 \\ \text { Cotton } & 0 & 0 & 0 & 0 & 0 & 0 & 0 & 0 & 2220 & 3832.50 \\ \text { Earthenware } & 0 & 0 & 0 & 0 & 0 & 0 & 0 & 0 & 32440 & 7435 \\ & & & & & & & & & & \\ \text { IN SuM } & 78855 & & 47601 & & 45605 & & 60506 & 56425.15 & \end{array}$

38 One may entertain doubts about some of the figures, since the relation between price and amount often varies greatly from year to year. "Kemiri" = Candlenuts, "Kacang iju" = Mung beans, "Kajang" = Awning, "Sirih hutan" = Sirih (betel) leaves from the forest, "Pinang nuts" or "areca nuts", often referred as betel nuts, "Kulit loba" = the bark of the loba tree, used to dye kain textiles, "Biji jarak" = Castor beans, "Kulit soga" = the soga tree is used to extract colour for batik. 
At the end a survey concerning the imported articles in $1946 .{ }^{39}$

$\begin{array}{rr}\text { Import Amount } & \text { Value } \\ 4,170 \mathrm{~kg} & 5,238 \mathrm{f} \\ 1,430 & 1,430 \\ 4,550 & 7,200 \\ 60 & 90 \\ 3,000 & 450 \\ 2,350 & 3,525 \\ 1,220 \text { jars } & 10,815 \\ 200 \mathrm{~kg} & 120 \\ 233 \text { pieces } & 850 \\ 10 & 50 \\ 20 & 20 \\ 50 \text { bottles } & 50 \\ 6 \text { bottles } & 60 \\ 1,350 \text { pieces } & 3,170 \\ 29,300 \text { pieces } & 5,673 \\ 35,000 \text { pieces } & 7,000\end{array}$

Coffee

Fish (dried)

Tobacco

1,430

Onions

Salt

Cotton

Gula air

Sugar (white)

850

Sarongs

Parangs

50

Knives

Sopi

Wine

50

Soap for washing

Sugar from Reo

5,673

Gula lempeng

35,000 pieces

45,741

IN SUM

The import of Nigieo ${ }^{40}$ goods amounted to $60,000 \mathrm{f}$.

\section{The Agricultural Guidance Service}

Since 1936 an Agricultural Guidance Service works on Alor and Pantar. The staff consists of:

An agricultural inspector who has attended the Cultivation School in Buitenzorg. ${ }^{41}$

Seven mantris ${ }^{42}$ of which the oldest has followed an agriculture course, while the younger graduates come from the agriculture class of the continuation school in Kalabahi; a single one followed an agriculture course in Tarus ${ }^{43}$ on Timor during the war.

The locations are, respectively:

a. Kalabahi for the kapitan-ship Dulolong

b. Atimelang for the kapitan-ships Limbur and Welai

c. Kabir for the kapitan-ship Pantar Matahari Naik

d. Blangmerang for the kapitan-ship Barnusa

e. Moru for the kapitan-ships Kui and Mataru

f. Probur for the kapitan-ship Probur

g. Kalaisi for the landschap Batulolong

h. Taramana for the landschap Kolana

39 "Gula air" = sugar juice, "Parangs" = cutlasses, "Sopi" = liquor, "Sugar from Reo" seems to refer to Reo in Manggarai, western Flores, "Gula lempeng" = literally flat sugar.

40 Nederlandsch-Indische Gemeenschappelijke Im- en Export Organisatie. Netherlands Indies Common Import and Export Organization.

41 Buitenzorg is the present Bogor, south of Jakarta on Java.

42 Malay, officials.

43 Tarus is situated in the vicinity of Kupang in West Timor. 
The working plan of the Agricultural Guidance Service encompasses the following points:

1. Improvement of the soil and shortening of the periods of fallow through campaigning for fertilizers and belukar ${ }^{44}$ restorers.

2. Propaganda for terracing through the piling of stones and living paggers ${ }^{45}$ of lamtoro, ${ }^{46}$ all after the situation of the terrain.

3. Reinforcement of the nutrition situation through propaganda for above all plants which are resistant to droughts.

4. Encouragement of the cultivation of commercial crops, whereby one would in the first place think of the planting of kacang $i j u ;{ }^{47}$ while in this year propaganda has started for the cultivation of coffee on the plots.

5. In this year, too, propaganda has started for the expansion of popular planting in between the rice and maize plantations. This is done with an eye on the great lack of textile products. In connection with this, a weaving school was opened in Kalabahi in October this year, where 15 girls from the mountain people of the district Dulolong are trained. The teachers, two old women from Kalabahi, are paid from the incomes of the selling of kain. ${ }^{48}$ There are also plans to open such a school in Moru (residence of the Raja of Kui) and in Kolana, next year.

6. Before the war, much propaganda was done for expanding the cultivation of kemiri, ${ }^{49}$ which succeeded after the degree of participation by the chiefs in question.

7. Aside from that, the encouragement of old plants such as klappers ${ }^{50}$ and pinang ${ }^{51}$ is likewise observed by the Agricultural Guidance Service. Hitherto the Agricultural Guidance Service has had real success only with the expansion of $u b i k a y u^{52}$ plantations. Two new variants were introduced, of which the Valenca is the most popular. Apart from that the population plants its own varieties, since these would be better suited to the making of gaplek. ${ }^{53}$ The Valenca variety is sweeter and therefore tastier. It is used for immediate consumption. The ubi kayu planting has now reached such dimensions that the end of the road towards the securing of nutrition can be seen.

\section{Cultivation of the soil}

The cultivation of the soil is also propagated. It is until now virtually limited to the plain around Kalabahi. On the elevated plains of the Kabola Peninsula, a beginning was made before the war. For the cultivation of soil, only the plains and the terrain that slopes only a little comes into question.

\footnotetext{
44 Underbrush.

45 Dutch-Indonesian word, from Malay pagar, fence.

46 The Leucaena glauca, a fast-growing tree that is used for firewood and also fodder.

47 Also called kacang hijau (green beans); mung beans, in East Timor called munggo.

48 Cloth, especially of sarong type.

49 Candlenut, a nut used both in Indonesian cuisine and in medicines.

50 Klapper, Dutch-Indonesian word, from Malay kelapa, coconut.

51 Betel nut.

52 Cassava.

53 Dried cassava.
} 


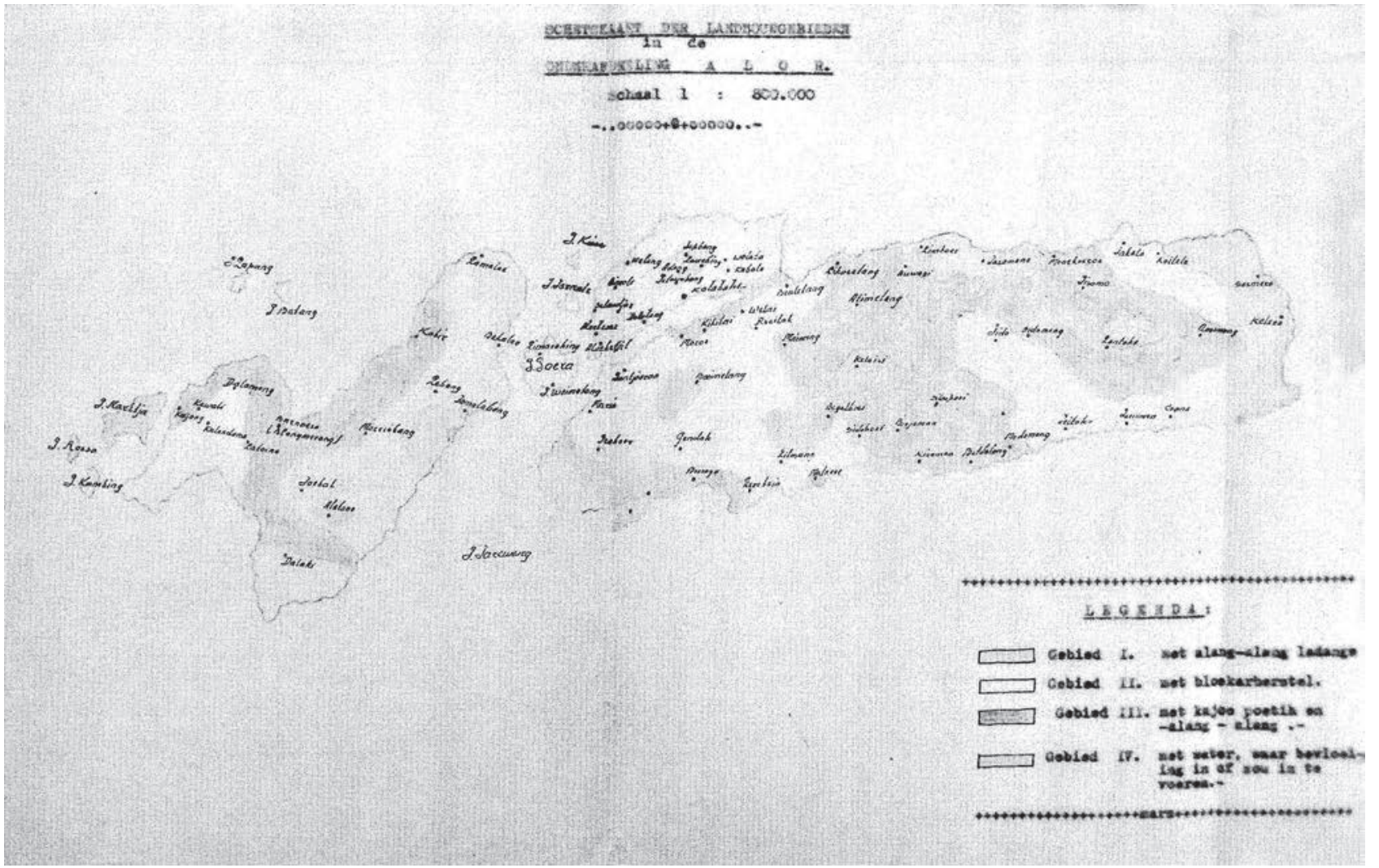

Languages and borders for the various princedoms on the Alor Islands.

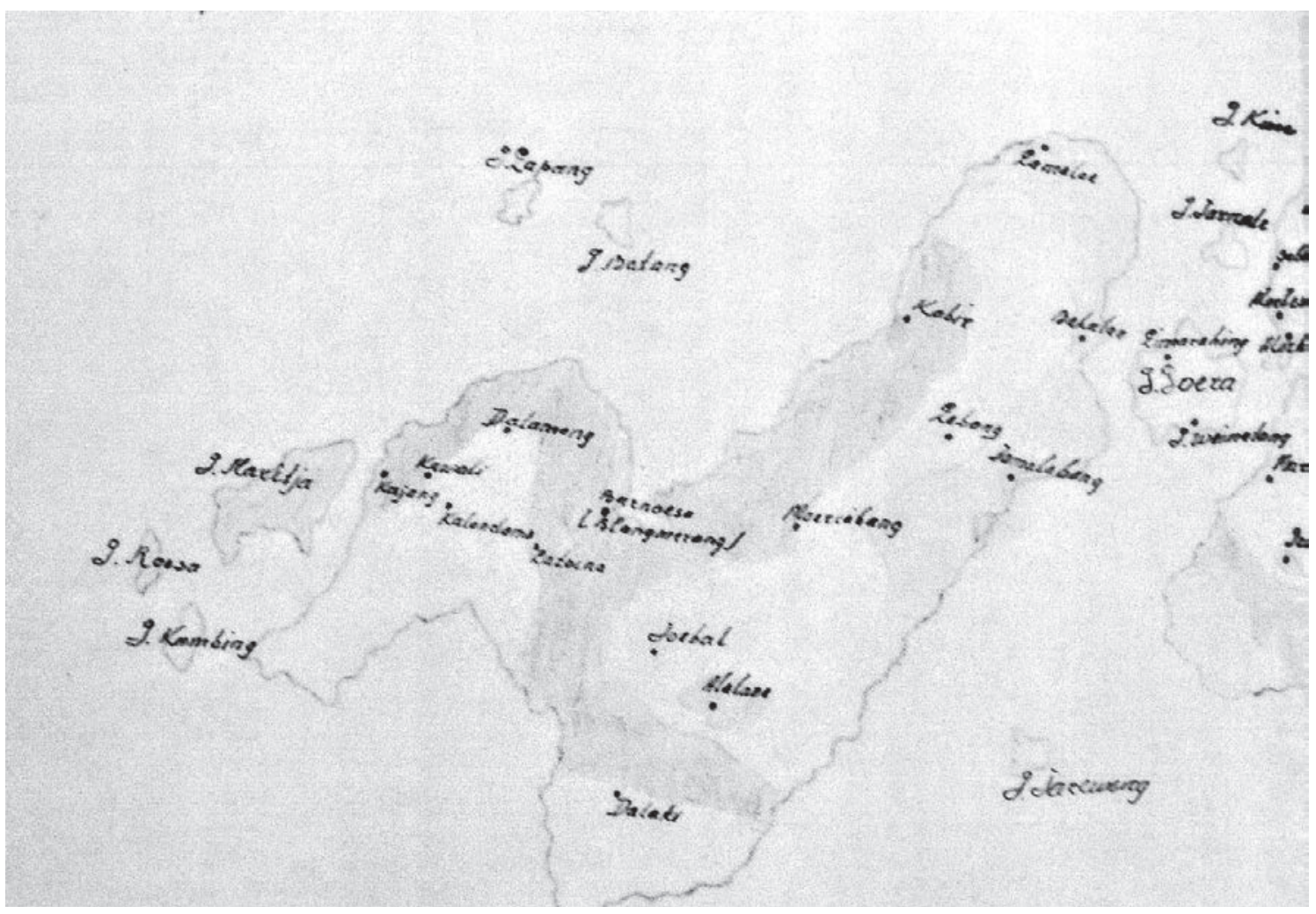



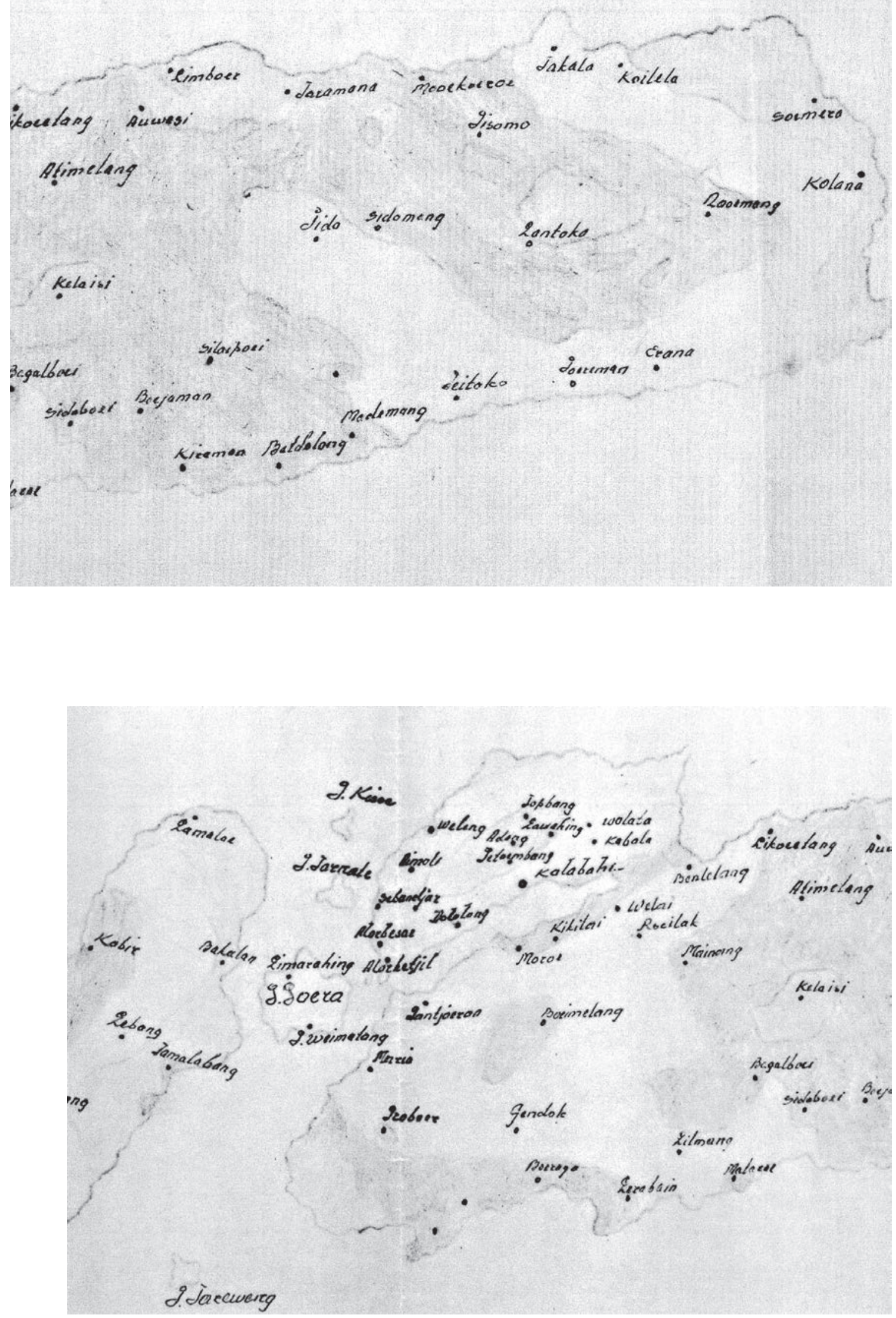


\section{Irrigation}

Irrigation is still not carried out to any degree. Along some rivers there are small watered plantations of keladi ${ }^{54}$ and so-called jagung air ${ }^{55}$ but these are not of any significance. The possibilities of irrigation are limited due to the stony terrain and the lack of extensive plains. However, there are a few possibilities such as the plains Mainang, Kalaisi and Tanglapui. The reclamation of these terrains and the possibilities of irrigation should take place in due time. At first, a great obstacle will persist in the very primitive population in these quarters and the lack of large domestic animals to use before the plough.

\section{Agricultural education}

Before the war an agricultural class was tied to the Governmental Continuation School in Kalabahi, which produced graduates for a few years. Through the demise of the agricultural teacher shortly before the outbreak of the war, and the impossibility to obtain a successor, the agricultural class had to be discontinued. A speedy reopening is much desired. Plans to provide agricultural education in popular schools, namely in schools where there is a fourth class, have not been carried out yet due to the lack of suitable teachers, In particular, I recommend my successor to pay special attention to this issue. At almost all the popular schools there are school plantations which are under the supervision of the guru and where the staff of the Agricultural Guidance Service provide instruction. The produce comes to the advantage of the school children and has also the aim to prevent absence from school during the lapar biasa ${ }^{56}$ periods. New methods such as the creation of terraces and the application of fertilizers are applied here and there on these plantations. They are also useful for the dissemination and multiplying of new planting stuff, such as occurred with the new $u b i$ kayu varieties, and is now happening with a brand of $u b i$ rambat $^{57}$ which was introduced from Bima $^{58}$ during the war.

Finally, a remark about the staff. The agricultural observer Karels was placed on Alor after his studies. He is quite diligent but has never worked under professional leadership. The visits by the agricultural consultant of Kupang have been sporadic and often limited to a visit to Kalabahi. In the interest of Karels himself, and in the interest of the Agricultural Guidance Service, it is desirable to dismiss and replace him with some skilled person who can work independently, pending the outlying situation of Alor. In my opinion, education of the mantris ${ }^{59}$ is still quite deficient. Good leadership should however partly meet this need.

To repeat, Alor has an almost exclusively rural population. Cattle-breeding, at least of large cattle, has no future due to the situation of the terrain. Thus it only remains to strive by all means to raise the standard of the farming, as the only possibility to bring this land forward economically. Appended is a sketch map of agriculture areas on Alor, taken over from the Memorie of Rijnders.

54 Taro.

55 "Water maize".

56 General hunger; the difficult period before the harvesting of the fields can take place.

57 Sweet potato.

58 The eastern part of the Island of Sumbawa, formerly a sultanate.

59 Low-ranking government employees. 


\section{Cattle-breeding}

Large cattle are practically absent in this Onderafdeeling. In 1930 the zelfbestuurders of Alor, Kolana and Batulolong each received a herd of one bull and 4 cows of Ongola cattle in accordance with the Sumba contract. The Raja of Alor alone now possesses some sixty sapi.$^{60}$ Close to Taramana a bunch of half-wild sapi belonging to the Raja of Kolana roam around, and they cause a lot of inconvenience to the inhabitants. Some individuals in Kalabahi and the landschap also have a number of sapi which are kept in the low plain between the Kabola Peninsula and the rest of Alor.

According to the most recent information the cattle population encompasses 215 horses, 193 sapi, 208 kerbau, ${ }^{61}$ 3,863 goats and 4,581 pigs. Horses are only used for riding. New import from Timor previously took place continuously. Sapi and kerbau are mainly kept around Kalabahi in order to provide the kota ${ }^{62}$ dwellers with meat and milk. A few plains along the coast might come into question for expanding the cattle-stock. The steep mountain terrain is unsuited for keeping large cattle.

In my opinion one must strive to expand the stock of small domestic animals, such as goats, sheep and pigs. Pigs are a valued possession among the mountain people. Where the ladang ${ }^{63}$ fields have no pagger, they are kept in pigsties at the edge of the kampongs. This method of rearing is quite costly, so that only the wealthier can permit themselves this abundance.

\section{Forest and sea products}

The export of forest and sea products mainly concerns the tamarind, kemiri, canari, ${ }^{64}$ batulaga ${ }^{65}$ and lola. ${ }^{66}$ Concerning the export statistics of these products, one may refer to the statistics on the export in 1941 and 1946.

\section{H. HEALTH}

The health conditions among the population are generally less than good. Partly, this is caused by the abhorrent situation in the field of hygiene, and partly due to the wartime conditions, when medical care was practically nil and the food situation constantly problematic. The coolies who returned from Timor were frequently suffering from dysentery and other diseases.

The foremost diseases are malaria, framboesia and skin diseases. Kalabahi, which was formerly notorious for frequent black water fever, has later been properly sanitized so that the health conditions are now fine. The spleen index before the war was about $30 \%$.

\footnotetext{
60 Cows.

61 Buffalos.

62 Town.

63 Dry ricefield.

64 Or pili nuts, canarium ovatum.

65 A water snail with green shell, turbo marmoratus.

66 Top shell, trochus niloticus. Both batulaga and lola are used for the mother-of-pearl contents of their shells, which are exported and used for decorative purposes.
} 
Immediately outside the sanitation area it rose to $90 \%$. During the war, cases of black water fever recurred.

The framboesia increased rapidly again during the war. Even among the Chinese it now occurs frequently. It will require some years of frequent touring before the governmental doctor has caught up with the disease.

The vaccination against smallpox was brought to a complete standstill during the war. Within short the vaccination shall be possible to carry out again. A vaccinator is present.

\section{Hospitals and polyclinics}

In Kalabahi a landschap hospital is found with a capacity of about 50 beds. The situation of the building can now be termed fine again. There is still a lack of many inventories and instruments. In Blangmerang in Pantar and in Kolana on the east coast of Alor, polyclinics have been established. The buildings are made of perishable material and serve until being replaced.

The pre-war personnel is still entirely present with the exception of the malaria mantri Pello Kila who has returned to Roti and put to work in the landschap hospital in Baä. ${ }^{67}$ Via the popular educators the schoolchildren are taught hygiene. A large part of the children are housed in boarding schools which encourages their awareness of washing regularly. As remarked above, going to church on Sundays supports cleanliness. However, there is much to improve here.

Especially the conditions of the living quarters are still the same as fifteen years ago. The cleanliness in the kampongs has improved since the government and the previous military and present police patrols have paid the necessary attention to it. However, in my view more could be achieved in this field through well implemented propaganda. That would in the first place be the task of the popular educators. Next, the office of vaccinator should be combined with that of hygiene mantri.

\section{Leprosy}

In the Onderafdeeling there were about 200 registered sufferers of leprosy before the war. More than thirty persons stay in the leprosy home that is under the supervision of the Indian Church. This leprosy home is situated about 1 kilometre from Kalabahi and consists of 10 houses, each of which can accommodate 4 leprous. There is also a central kitchen, a polyclinic with an annex that comprises a hospital ward for 10 patients, and a mantri house. A pipe with running water ensures the removal of faeces, etc. The governmental doctor in Kalabahi ensures medical care.

The medicine, band aid, etc., and the foodstuff, is at the expense of the landschap. To the leprosy home belongs a substantial patch of land where the leprous can cultivate a garden insofar as they are in the state to do so. The aim, the safety of the community against the peril of contamination of this feared sickness, apart from the aim of securing the livelihood of these unlucky ones, is only partly fulfilled. Firstly, since only part

67 Baä is the principal administrative centre on the Island of Roti (Rote), west of Timor. 
of the leprous are taken care of; and secondly, since the leprous who are cared for often leave the leprosy home and are found in the surrounding kampongs.

The latter can not be entirely avoided, but better supervision by the administrator, namely the Indian preacher and the specially hired leprosy mantri, who is in the service of the Indian Church, should be able to improve things. The small island Ternate or Pulau Kisu between Alor and Pantar is a true source of infection of leprosy. It is recommended with respect to the governmental doctor that a prohibition of residence is obtained from the local rulership.

\section{RULE}

\section{a. Native rule}

It may be confidently assumed that the smallest original community was the family. In each kampong (at any rate in the mountains) only one family resided with its own governing structure on three levels, namely that of the family headman, the orang kaya ${ }^{68}$ or rulers, and the kapitan or war leader (see under Population). Later, several families often resided together through a split of the original family or through the movements of other families. These families remained independent as regards their own affairs, while the concerns of the settlement were settled by the abovementioned three-tiered governance. These functions were often split between the families.

The independence of the families, regarding family matters such as marriage, divorce, burial, etc. has mostly persisted. As kampong headmen, our government has frequently acknowledged one of the family heads or one of his closest kinsmen. Thereby the foremost families had the priority, although the question of how developed they were also played a prominent role. In some areas such as the Kabola Peninsula, West Pantar and elsewhere, where new families emerged through division, a certain tie persisted between the mother kampong and the emigrants. In case of warfare they supported each other, whereby one particular settlement enjoyed the highest prestige.

These grand chiefs, as one may call them, were employed as temukungs under the controleur Boeman in 1930. These temukungs ${ }^{69}$ indeed have some power over the subordinated kampong chiefs, so that this new function can be called successful. In other areas, where these connections do not occur, temukungs are likewise employed. They are sometimes headmen of a kampong in a particular territory, which in terms of adat law does not form a unity. Thus it may occur that several languages are spoken in such a temukung-ship, and that the inhabitants have quite diverse origins. One may refer to the "Survey of the origins and affiliation of the

68 Orang kaya is a Malay word meaning rich man, and is used in various part of Indonesia for local men of power or wealth.

69 From the Malay-Javanese term tumenggung, a noble title used for regents on Java, and ministers for justice, defence and palace affairs in the Malay world. 
population of the landschap Batulolong", which is appended to this Memorie. ${ }^{70}$ That the power of these temukungs is very small goes without saying.

Above these kampong heads and temukungs are the kapitans. Originally each raja had a kapitan at his disposal to exert power (here, kapitan should not be understood as a war leader). Later on, through the merger of landschappen, or since the area of the landschap was too large, several kapitans were employed. The present kapitans are as follows.

The landschap Alor consists of the kapitan-ships:

a. Dulolong, Kapitan Elias Nampira, a kinsman of the raja.

b. Welai, Kapitan Jafar Koho, from one of the foremost families of Dulolong.

c. Limbur, Kapitan Saleh Tulomau, from the raja family of Alor Besar.

d. Pantar Matahari Naik, Kapitan Tahir Noke, a grandson of the Raja of Blagar (Pantar).

e. Barnusa, Kapitan Amu Blegur, son of the kepala besar ${ }^{71}$ of the mountain people of West

Pantar of the so-called Lemma group.

The landschap Kui consists of the kapitan-ships:

a. Kui or Lerabaing, Kapitan Makunima Makunima from the kapitan family of Kui.

b. Probur, Kapitan Thomas Loban, son of the kepala besar of the kampong Mataraban (Probur).

c. Mataru, Kapitan Balsasar Sukurkoli from the kapitan family of Mataru.

The landschap Kolana consists of the kapitan-ships:

a. Kolana, Kapitan Jonathan Berimau from the kapitan family of Kolana.

b. Taramana, Kapitan Michël Tubulau, whose grandfather originated from Timor Dilly.

He is married to the sister of the Raja of Kolana.

c. Pureman, Kapitan Benedictus Manukoi, son of the Raja of Pureman.

The landschap Batulolong consists of the kapitan-ship of the same name. The kapitan is Christoffel Laubela from the kapitan family of Batulolong.

\section{b. European rule}

After the agreement of $1853^{72}$ between Portugal and the Netherlands, where Portugal among other things abstained from its pretensions to the Alor Island in exchange for Pulau Kambing ${ }^{73}$ (opposite Timor Dilly), a posthouder ${ }^{74}$ was placed at Alor Kecil at the entrance of the Kabola Bay. After our more substantial efforts with these islands, the Onderafdeeling came under the

70 Unfortunately this survey is not found in the copy of Van Galen's Memorie in the Nationaal Archief.

71 Grand headman.

72 Probably meaning 1851, when the first agreement between the Governor of Dili and the representatives of the Dutch East Indies was concluded. It was subsequently renegotiated and confirmed in $1859-60$.

73 "Goat Island", otherwise known as Ataúro; an island situated 25 kilometres to the north of Dili, today belonging to Timor Leste.

74 Post-keeper, a representative of the colonial power. 
governance of the military commander. Later on, Alor came under civil administration with the exception of the yeas 1934-1937. The Onderafdeeling Alor belonged in turns to the Afdeeling Timor and Islands and the Afdeeling Flores, and now belongs to the Afdeeling Timor since 1938.

\section{c. Public facilities}

\section{Roads}

The roads in the Onderafdeeling consist of horse-paths which are usually quite properly made. The breadth varies between 1,5 and 2 meters. Along the steep mountainsides they run upwards in a sometimes endlessly meandering zigzag pattern. Their total length is estimated to be about 500 kilometres. There are no roads for automobiles. Certainly there is a road of sufficient breadth from Alor Kecil along the coast of the Kabola Bay to Kalabahi and subsequently to Moru at the upper side of the bay, and to Likuwatang at the north coast. The bridges that are standing there are however unsuited for motor traffic.

The construction of roads for motor traffic can only take place at great costs due to the situation of the terrain. From an economic point of view that would not be justified since the costs of transport via perahus from the various coastal places to Kalabahi are much cheaper. The distance from the mountain area to these coastal places is mostly no more than 25 to 30 kilometres.

Before the war there were the following telephone lines:

a. From Kalabahi to Alor Kecil at the entrance of the Kabola Bay.

b. From Kalabahi across the island to Kolana at the east coast of Alor with side connections to Peitoko-Batulolong and to Taramana.

c. From Kalabahi to Moru and Lerabaing at the south coast.

These telephone lines were broken, partly during the insurrection of the mountain people, and partly by the Japanese. Only the connection to Moru is once again in order. Materials for the restoration of the telephone lines have been requested and should be partly received within short time. A good functioning telephone connection is virtually indispensable for a good exercise of government in this inaccessible area. For the communication with Pantar a local boat was available. A motorboat can be expected within short. 


\section{d. Landschap funds}

1. The foremost source of income is the "Taxation on enterprises and other incomes". Below is a survey concerning the harvesting of this tax in the years 1934, 1935, 1936, 1937, 1941, 1942, and 1946-1947.

$\begin{array}{lrrrr}\text { Assessment } & \text { Income } & \begin{array}{r}\text { Number } \\ \text { of tax payers }\end{array} & \begin{array}{r}\text { Medium } \\ \text { assessment }\end{array} \\ 1934 & 34,809.47 \mathrm{f} & 15,957.29 \mathrm{f} & 20,430 & 1.60 \mathrm{f} \\ 1935 & 22,799.86 \mathrm{f} & 22,951.25 \mathrm{f} & 20,799 & 1.10 \mathrm{f} \\ 1936 & 26,918.34 \mathrm{f} & 26,924.99 \mathrm{f} & 21,205 & 1.27 \mathrm{f} \\ 1937 & 32,127.77 \mathrm{f} & 31,274.52 \mathrm{f} & 21,356 & 1.50 \mathrm{f} \\ 1941 & 34,494.95 \mathrm{f} & 34,300 \mathrm{f}(\text { est.) } & 20,380 & 1.70 \mathrm{f} \\ 1942 & 35,000 \mathrm{f}(\text { est.) } & 35,000 \mathrm{f} \text { (est.) } & 20,380 & 1.70 \mathrm{f} \\ 1946 & 19,000 \mathrm{f}(\text { est.) } & 19,000 \mathrm{f} \text { (est.) } & 17,800 & 1.07 \mathrm{f} \\ 1947 & 53,400 \mathrm{f}(\text { est.) } & 50,730 \mathrm{f} \text { (est.) } & 17,800 & 3 \mathrm{f}\end{array}$

On this, $40 \%$ were levied, namely $20 \%$ on behalf of the school funds and $20 \%$ on behalf of the common funds. The diminished number of taxpayers is apparent. This is possibly due to the greater mortality during the war through participation in the insurrections, and mortality among the coolies on Timor. It is however more likely that a large number of persons have withdrawn from tax assessment. Now that the conditions are normal the number of taxpayers is expected to rise in 1947.

2. Taxes on the slaughter of cows, buffalos and horses. This is very small. The statistics for this are:

\begin{tabular}{|l|r|}
\hline 1934 & $229 \mathrm{f}$ \\
\hline 1935 & $169 \mathrm{f}$ \\
\hline 1936 & $71 \mathrm{f}$ \\
\hline 1937 & $148.50 \mathrm{f}$ \\
\hline 1938 & $101 \mathrm{f}$ \\
\hline 1939 & $115 \mathrm{f}$ \\
\hline 1940 & $68 \mathrm{f}$ \\
\hline 1941 & $100 \mathrm{f}$ (est.) \\
\hline 1942 & $75 \mathrm{f}$ (est.) \\
\hline 1946 & nil \\
\hline 1947 & nil \\
\hline
\end{tabular}




\section{Bea penghasilan ${ }^{75}$}

\begin{tabular}{|l|r|}
\hline 1934 & $700.39 \mathrm{f}$ \\
\hline 1935 & $1,367.41 \mathrm{f}$ \\
\hline 1936 & $1,316.78 \mathrm{f}$ \\
\hline 1937 & $1,236.05 \mathrm{f}$ \\
\hline 1938 & $1,552.04 \mathrm{f}$ \\
\hline 1939 & $1,440.20 \mathrm{f}$ \\
\hline 1940 & $2,623.77 \mathrm{f}$ \\
\hline 1941 & $3,000 \mathrm{f}$ (est.) \\
\hline 1942 & $2,000 \mathrm{f}$ (est.) \\
\hline 1946 & $3,500 \mathrm{f}$ (est.) \\
\hline 1947 & $3,000 \mathrm{f}$ (est.) \\
\hline
\end{tabular}

The incomes are moving upwards.

\section{e. Corvée labour}

The corvée labour was abolished on 1 January 1942 at the same time as the introduction of the regulation of "road funds taxation". For 1946 this road fund amounted to 1 guilder per person. For 1947 this is calculated to be 3 guilders per person. It is expected that the great majority of those liable to pay road funds will fulfil their payment through work on the upkeep of the horse-paths. It is estimated that a tenure of about 12 days per person is sufficient for this upkeep, which would correspond to a coolie wage of about 0,25 guilder per day.

\section{f. Justice}

Legal matters are exercised by the Ruler's Court and the Council of Chiefs of the Land. The competence of these bodies of justice accord with that of the previous Magistrate Courts and Land Councils. The verdicts of the Ruler's Court can not be implemented without the affirmation of the head of the Onderafdeeling. The verdicts of the Council of Chiefs of the Land can be revised by the head of the Afdeeling and the resident. ${ }^{76}$

At the Ruler's Court the zelfbestuurder is the sole judge. The council of Chiefs of the Land is chaired by the zelfbestuurders in question, while the other zelfbestuurders and the kapitans are members of this legal board. The head of the Onderafdeeling acts as leader.

Crime rates are not high in this Onderafdeeling, which may be seen from the following table [next page!] of crimes brought to justice:

75 Duties on the produce.

76 That is, the resident in Kupang. 


$\begin{array}{lcccc} & 1935 & 1936 & 1937 & 1946 \\ \text { Murder } & 3 & 1 & 4 & 3 \\ \text { Manslaughter } & 0 & 1 & 2 & 1 \\ \text { Mistreatment } & 3 & 0 & 4 & 3 \\ \text { Fighting } & 0 & 1 & 0 & 0 \\ \text { Arson } & 0 & 0 & 1 & 2 \\ \text { Sexual offences } & 3 & 1 & 3 & 1 \\ \text { Other offences } & 4 & 4 & 7 & 6 \\ \text { Theft } & 4 & 3 & 3 & 6 \\ \text { Collaboration } & 0 & 0 & 0 & 2\end{array}$

\section{POLITICAL SITUATION}

About this, the Memorie of K. Rijnders says as follows.

1. In this Onderafdeeling the following associations occur:

The Assirathal Mustaqim (A.M.), an association that was previously limited to purely religious matters, but which has now also began to make an effort to provide relief. This is provided through an attorney for those members who have been involved in some legal issue. Thus in 1937, the chairman of the Partai Sarekat Celebes (Parsas), Mr. Lengkon, arrived here to act as advisor for some Butonese who were involved in a civil legal matter.

\section{The Partai Serikat Islam (P.S.I.). ${ }^{77}$}

This association caused much trouble for the government in 1933-1934, first because of their fiery resistance to taxes and corvée service; and second because they undermined the power of the zelfbestuur and the power of the lower chiefs; and third since they did not care about the existing adat; and fourth, due to their provocative stance towards the European government. Zelfbestuurders and lower chiefs stood virtually powerless to deal with this association, and when the European government at a time dealt with these gentlemen somewhat harshly but entirely justified, it was not always taken lightly by those with a ringside seat.

The handling of power was also deplorable. The members only listened to their leaders while the zelfbestuurders and chiefs were confronted in an utterly obnoxious and provoking manner. In 1935 this association was, by the decree of the resident, dealt with concerning the payment of taxes and corvée service, which was quite necessary since the members had not paid one cent in taxes since 1931, though they each year paid a membership fee of 1.40 guilder. However, this happened in a somewhat harsh manner and a wooden cudgel was handled once in order to put some force behind the execution of the government decree. It goes without saying that this resulted in a complaint being submitted to the highest level. And what was more important: part of the missing tax

77 The Sarekat Islam, Islamic Union, was an association formed in 1911-13 under the leadership of R. Oemar Said Tjokroaminoto. Its aims were to work for the interests of the people and encourage agriculture, trade, health, education and religious life (Gonggrijp 1934, pp. 1268-71). It was an important step towards the formation of an Indonesian nationalist consciousness. The element "Islam" in the name in the first place indicated that the association was not Chinese or Christian-European. 
payments of the previous years were harvested, and part of the P.S.I. members furthermore withdrew.

One of the strongest arguments in favour of becoming a new member of the forerunner of the P.S.I. was the saying, "Be a member too; then you do not need pay taxes and not perform any corvée service; that you always see with us". This promise found a willing ear among the primitive mountain people. The result was that these became members and did not pay any taxes, or that they did not become members but still paid no taxes, since they said, "why we and not them?" When tax number one was harvested from the P.S.I. members and it was insisted that they pay, on which occasion we helped them to work to earn the payment, then several members resigned their membership, and those who were not members even paid much more smoothly and affluently.

In the following years a forceful harvesting of taxes from the P.S.I. members was carried out, so that membership dropped sharply by 1937, although the chairman of the L.M.P.S. tried to breathe some new life in the association in August 1936. At the moment there are still cabangs $^{78}$ of the P.S.I. in Dulolong, Lewolang, Lewalu, Alor Besar, Timuabang - situated only on the peninsula - and the kampongs Blangmerang and Kayang on Pantar. We have not heard anything more from this association, the members behave normally and once again keep to the local adat, thanks to some prison terms that were administered among them.

\section{The Partai Serikat Islam Indonesia (P.S.I.I.) ${ }^{79}$}

In 1936 this association, which supports a cooperative policy, split from the P.S.I. that honours the initial non-cooperation. The base of this association is settled on Java. Party leader is H.A. Salim, disbarred member of the P.S.I.I. on Java. One encounters cabangs of this association in Dulolong, Lewolang, Lewalu, Umapura, Topubang - all in the Bird's Head of Alor. ${ }^{80}$ So far we have heard little from this P.S.I.I. It is nevertheless a concern to secretly monitor the movements and attitudes of the members, so that one may, at the first attempt to revert to their old fiery resistance, take action immediately and in a tough manner, and resolutely support the zelfbestuurders in countering this movement. In a primitive land, as Alor still is, every political association is detrimental since the population itself is too stupid to comprehend anything, let alone deal with politics. They thus run the risk of being exploited by a few well-spoken representatives and do not only lose their money to the association but are also afflicted by adat punishments or penal laws since they do not understand the words of the leaders, or interpret them incorrectly. [Thus far the quote from the Rijnders Memorie.]

\footnotetext{
78 Branches.

79 This is a bit vague in Van Galen's account. The Partai Sarekat Islam Indonesia was actually formed in 1929 at a Sarekat Islam congress in Batavia, being a continuation of the S.I. By 1934 it had some 30,000 members with 135 local branches (Gonggrijp 1934, p. 1271). According to Widiyatmika (2007, p. 357-8), the P.S.I.I. sub-branch in Dulolong was established in 1932 with Umar Bara Pa and H. Dasing as leaders. Due to its campaigns for tax refusal, the leadership was threatened with arrest by the colonial authorities. Umar Bara Pa and H. Dasing managed to slip away, but another figure called Kalipang was jailed in Kupang for three months. The organization later split into P.S.I. and P.S.I.I.

80 The north-western peninsula, slightly reminiscent of a bird's head.
} 
During my stay on Alor from the beginning of 1939 to March 1942, the members of the P.S.I.I. usually kept to the laws of the land. The anti-government tendency nevertheless persisted. Particular disciplinary action did not need to be carried out. The harvesting of taxes and the demands for corvée services needed the necessary attention, but did not result in any particular trouble. With the outbreak of the mutiny of the military detachment in Kalabahi, the leaders of the P.S.I.I. immediately joined the mutineers. Pioneer groups were summoned to perform patrol service in the military encampment and in the kota Kalabahi.

The P.S.I.I. quickly turned to make the mountain people of the Kabola Peninsula convert to Islam, more or less under threat. This provoked resistance among the Christian community in Kalabahi and among the Christian mutineers. The result of this was that the P.S.I.I. were brought back home including the pioneer groups, the more so since these made use of the patrolling to plunder in the Chinese encampment.

During the Japanese period the political associations were at first shut down. During the last year of the occupation, the Persiapa (Siap = Serekat Islam Alor Pantar) was established. Apart from its attention to the Mohammedan population, it had the collaboration with the Japs ${ }^{81}$ until the final victory written in its statutes. The headmen of this association, which was established at the decree of the Japanese commander Tomiki, were Beleng Maleng (sentenced in 1940 due to embezzlement of tax money and false writings), Mohammad Idris, imam of Dulolong, Mohammad Tahir from Dulolong, father-in-law of the raja muda, Raja Muda Achmad Bala Nampira, and Sulaiman Abdullah, merchant in Kalabahi.

After the departure of the Japs in September 1945, collaboration with the Japs was erased from the statutes, and some time after the return of the Dutch government in November 1945, the association was shut down. During the first half of 1946 there was no trace of political activity. Seemingly the leaders, especially in Blangmerang where they had been most loud-voiced, had somewhat lost their vision, or else they feared penal consequences for their pro-Japanese and anti-Allied expressions. In the second half of 1946 one could notice more activity concerning associations. In October a Mohammedan youth association was formed, the "Pemuda Muslimin Pantar" which had the goal to further the interests of the Mohammedan youth, especially in the religious field. On 8 November the Parmuti ("Partai Muslimin Timor") was established, likewise in Blangmerang. The goal was the furthering of the interests for the Mohammedan population, also in collaboration with other similar associations in Indonesia on the basis of the principles of the Malino conference. ${ }^{82}$ In November, a "Majelis Islam Alor Pantar" was established in Dulolong under the leadership of Mohammad Idris, the imam of Dulolong. Its goal was to unite the precursors in the religious field and inspire them to greater attention to for

81 Jap, jappen, Dutch colloquial and contemptuous expression for the Japanese.

82 A conference arranged by the Dutch in Malino in South Sulawesi in July 1946. Various rajas and interest groups from Kalimantan and eastern Indonesia agreed to the idea of a federal state that ensured a continuation of Dutch presence. However, the Indonesians also required a measure of genuine autonomy to the surprise of the Dutch organizers (Ricklefs 1981, p. 212). 
their task. A subdivision of the association Pemuda Muslimin Pantar, a pioneer division called "Persatuan Pemuda Islam Afdeeling Pandu" (Perpiap), was established on 29 November 1946.

The political situation in this Onderafdeeling can be termed advantageous. Nationalist currents occur among the zelfbestuurders as well as the more developed part of the population; this, however, is a sound nationalism. It is realized that cooperation with the Dutch to build these quarters can not yet be missed.

Elections held this month for the Island Council of Timor caught sufficient attention. The "Dewan Raja"83 and the "Dewan Perwakilan Ra'yat" "84 are new establishments which, it is discerned, are necessarily connected to the changed circumstances. But the range of this is still not realized. As for the situation of this Onderafdeeling during the Japanese occupation one may refer to the appendices:

a. General survey over the Onderafdeeling Alor over the period 3 to 22 November 1945.

b. The insurrections of the mountain people of Alor against the Rajas of Alor and Kui.

Kalabahi, 15 December 1946

The functioning controleur of Alor

G.A.M. van Galen

\section{Note on sources:}

1. Memorie van Overgave of the first lieutenant of the infantry, functioning commander of Alor, K. Rijnders, 3 January 1938.

2. De sociale structuur van een Aloreesche bevolkingsgroep [The social structure of an Alorese population group] by M.M. Nicolspeyer.

3. Military Memorie of Alor and Pantar, dated 16 January 1930.

\section{Appendixes:}

1. Pedigrees of the raja families of Alor, Alor Besar, Kui, Kolana, and Batulolong.

2. General survey over the Onderafdeeling Alor over the period 3 to 22 November 1945.

3. The insurrections of the mountain people of Alor against the rajas.

4. Survey of the ancestry of the population of the landschap Batulolong, September 1946.

5. List of the adat denominations of the families, clans and power-holders.

83 The Raja Council of the Timor Residency, where the various local rulers convened.

84 Council of People's Representatives, House of Representatives. 


\section{Copy. \\ Insurrections of the mountain people of Alor against the rajas}

Even before the mutiny of the military detachment in Kalabahi, ${ }^{85}$ there was dissatisfaction in the Limbur territory over the behaviour of the Kapitan Limbur, Anwar Koko Panggo. About one month previously, complaints about this were taken to Kalabahi. The kapitan had allegedly trapped and beaten temukungs and kampong chiefs, and given them food mixed with faeces.

While this case was investigated, the mutiny broke out and the [Dutch] power in Kalabahi vanished into air. The rajas themselves were hardly safe from the mutineers. These were attracted to the allure of rulership but spent their time in plundering and gambling. Soon after the mountain people announced that now that the "pemerintahan" 86 had vanished, they felt liberated from the duty to pay taxes and perform corvée labour. When Kapitan Limbur arrived to hand out the assessment notes the population refused to appear before him. Telephone thread was cut off to make arrowheads, visitors to the pasar $^{87}$ in Binlelang were robbed by armed bands, and even a head was taken. Kapitan Limbur brought report to the Raja of Alor, and he asked the Javanese sergeant Rakimin, who alleged to be the headman of the local government, to send a patrol.

The kapitan now departed with about 10 soldiers in order to repair the telephone line. He remained behind at the bivouac at the kampong Likuatang since the former militaries proceeded to Taramana. After the patrol was on its way again, a large group (about 600 men according to the kapitan) of mountain people armed with bow and arrow descended in order to kill the kapitan. He escaped by jumping into the sea and reached a perahu. The mountain people subsequently attacked the patrol and put them to flight until Taramana where they embarked on perahus. The Raja of Alor vainly summoned the temukungs and chiefs to appear. Each day more kampongs joined the uprising. The kapitan-ship Welai also took the side of the uprising. The house of Kapitan Welai was burned and the kapitan tua could just barely escape. The main instigator in the Limbur area was the temukung of Atimelang, Maleiata Karma, an inhabitant of the kampong Dikengpea called Thomas Atalanga, and Maleiseni Senialuka from the kampong Alukawati. From Welai, the most important man was the temukung of Welai, Michael Lakamau. Maleiseni Senialuka supposedly enticed a kampong dweller from the kampong Bakudata to make jimat ${ }^{88}$ from roots, wrapped in red patches. These invulnerability-bringing jimat were sold among the insurgents on a grand scale for 0.02 guilder per piece, and became the symbol of the resistance. Insurgents went from kampong to kampong: "If you want to buy this jimat, it is a token that you join us; if not, then you support the raja and then we shall kill you."

85 In connection with the Japanese onslaught on the Timor area in early 1942, a mutiny took place among the local troops on Alor, forcing out the Dutch. Japanese air attacks on Timor started on 26 January, and on 20 February the invasion commenced. Timor was held by Dutch, Australian and British troops which were however defeated by the invaders in three days time (Farram 2003, pp. 166-9).

86 Rule, in this case Dutch rule.

87 Bazaar, market.

88 Talismans. 
The feeling of invulnerability and the fact that the mutineers of the Kalabahi detachment did no longer dare to go on patrol, awoke the enthusiasm for the insurrection even more.

In June 1942 the first Japanese ship arrived to Kalabahi. These gentlemen remained here for two days and brought along all the firearms and munitions at their departure, apart from 25 carbines and 350 cartridges which were left behind in the $\operatorname{tangsi}^{89}$ at the request of the Raja of Alor.

The mountain people could hardly be kept back any more, and announced that they would set fire to Kalabahi. The insurrection expanded to the division Mataru in the raja-ship Kui. Here too, the mountain kampongs refused to pay taxes. They furthermore lodged a demand: the return of the pusaka $a^{90}$ that were taken away by the raja in 1918. These moko had supposedly been taken as "booty" by a military punitive expedition in this area. On 19 July the Raja of Kui received a letter from the head of the school in Lilmang where he warned that the population of Manet wanted to stage an uprising.

About this time the insurgents of Welai and Atimelang in fact tried to invade Kalabahi. They were however beaten back about 2 kilometres from Jembatan Hitam by some former militaries supported by kampong dwellers from Kalabahi and Alor Kecil. At this the latter took heads as booty, which were displayed in the kampongs under the customary festivities. Even the imam of Alor Kecil came back home with a head. In Kalabahi there was then real panic; the Chinese were sitting on board the Binongko ${ }^{91}$ perahus which lay ready to sail by Kalabahi and Moru. Kampong people fled to Alor Kecil.

The uprising expanded steadily through the great activity of the insurgents who by and by threatened more kampongs and ravaged some kampongs, such as happened in Mataru (Kui). In the raja-ships Kolana and Batulolong the insurgents could however gain no adherents.

On 21 August the Kapitan of Mataru, Thomas Solokale, appeared before the Raja of Kui in order to bring up an issue concerning a woman. The raja then asked about the situation in Lilmang, upon which the kapitan gave a very reassuring answer. It was rumoured in the Mataru kampongs that the kapitan had been killed by the raja. The insurgents opined that they must take revenge for this "murder" by killing the Kapitan of Lerabaing, so that they could, apart from that, retrieve the mokos. The raja hurried to send a letter with the notification that the kapitan was safe and sound, but the courier, the 12-year old son of the temukung of Kamalelang, was killed by the insurgents from Manet, and the letter was torn.

In the same day the insurgents from the kampongs Manet, Makalelang, Arusbui, Bogalbui, Builola and Laiwasi performed an attack on Kamalelang, shot and killed an inhabitant called Maikari Likamusi, burned the houses, ravaged the gardens and stole cattle and other barang. ${ }^{92}$ Then, two days later, it was the turn of the kampong Lilmang; here, 3 inhabitants were killed. In order to persuade the insurgents, Raja Kui sent the Kapitan of Mataru himself. However, not even this helped. They acted as they did not recognize him and chased him away ignominiously, sending arrows and curses after him. Furthermore, they plundered the kampongs Biabui and

89 Barracks.

90 Heirlooms.

91 Binongko is an island in the Tukangbesi group east of Buton, north of Alor.

92 Things, goods. 
Buktaga in the same day. The bands had by now arrived in the vicinity of Lerabaing and one could expect an attack on this kampong.

At this moment a Binongko perahu arrived to the threatened place with eight Japanese from the Otori ${ }^{93}$ on board. They left three rifles and 300 cartridges there before proceeding to Kalabahi. A retired military and the temukung drove the insurgents back with the help of these weapons, whereby two mountain people were shot dead. Meanwhile the people of Limbur undertook yet another raid in the territory of the Raja of Kolana, and at Taramana they took the head of a Chinese.

The Japanese sent message from Kalabahi, telling the leaders of the uprising to appear. These would only, however, appear if the stolen pusaka had first been returned. Then a second troop of Japanese appeared, being about 60 marines under the command of a certain Nakamura. These people acted in such a way in the Welai and Atimalang quarters that Mataru stopped out of fear and the chiefs of that area came and reported themselves. The kampong chiefs of Manet and Builola were in fact put in prison.

In Welai, kampong Ruilak, the Japs shot 5 people dead, whereupon the people in this quarter came to Kalabahi to ask for forgiveness. In Atimelang several kampongs were burned (Rolmelang, Lawatika and 7 other kampongs) and the kampong chiefs of Atimelang and Lawatika were killed. After the punitive expedition the people of Limbur came and reported. Of these, the temukung of Atimelang, the kampong chief of Dikingpea and the medicine man Thomas Atalang, were apprehended and soon after brought to Kalabahi together with the two abovementioned kampong chiefs from Mataru. They were shot dead close to the Christian cemetery in the view of the present mountain people. On the following day the temukung of Welai was finished off with the bayonets at the same place. These executions marked the end of the first uprising of the mountain districts.

During the entire Japanese action, one Japanese man was severely wounded by an arrow shot from an ambush. In September, when the actual uprising in Mataru had already ended, the Raja of Kui went to the border to Batulolong in order to inspect klapper plantations. He was attacked there. During this assault some insurgents were shot dead by the escorting police.

The Japanese garrison was replaced after only two months. In the beginning of 1943 this replacement headed back for Kupang, leaving the rajas to their fate. The game now started anew, rebellious kampongs rose again and disturbed other kampongs, and the jimat trade flourished once more. In no time at all, Limbur and Mataru were once again in commotion, the tax demands in 1943 were refused, and letters of admonition were torn. The first attack concerned a police patrol of five men that was assaulted close to Atimelang. They hoped to counter the five chiefs killed or executed by the Japanese with the skulls of the members of the patrol. The assault failed, two agents were wounded and a few attackers were killed.

On 20 February the Raja of Kui went to Lerabaing in order to hand out tax notifications, but only a few chiefs appeared. The kapitan related to him that the insurgents from Manet and oth-

93 Perhaps alluding to the $\bar{O}$ tori, a torpedo boat launched in 1935 and sunk off Saipan in 1944. 
ers would not pay any taxes. In their lego-lego pantuns, the discontent praised "tuan Padalawai" who originated from Bakudata. This tukang obat ${ }^{94}$ was once again busy providing new jimat.

In the beginning of March there came a report that a head had been taken. A boy of 12 years from Kamalelang was the victim. The men from Kamalelang, Rumalelang and Builola came in arms to inquire about it, and the episode ended in a fight. Through this one man from Rumalelang fell into the hands of the enemy and was killed. The foremost instigator in Mataru was Marcus Mabahala from Bogalbui and the dismissed agricultural mantra Salmun Kamengmi from the kampong Adiawasi. They brought up the moko story from 1918 and issued a declaration that they would no more acknowledge the Raja of Kui. A certain Belamo was made Raja of Mataru.

The raja muda of Alor withdrew to Kupang in order to acquire assistance and returned with the Japanese O. Ogisaka, who became the head of the Minseibu ${ }^{95}$ in Kalabahi, and with an interpreter called Seto. Ogisaka wrote several letters to the insurgents and summoned them to Kalabahi, though without result. The Raja of Kui paid a visit to the Jap who charged him to bring 30 moko to Mataru so that these people could once again reconcile with him. The raja subsequently bartered a moko makassar tanah against 31 small moko and gongs and summoned the chiefs of Mataru to appear in Moru. This happened but the moko were not accepted. According to the chiefs their old pusaka had been much more valuable.

Since the policemen who guarded the border between Limbur and Welai were repeatedly attacked, the Japanese interpreter returned to Kupang and fetched reinforcements: 30 former militaries from the K.N.I.L. ${ }^{96}$ who were incorporated in the police force. In August this new police force performed an expedition against the rebellious areas. The mountain people from Limbur hid in the bed of a kali. ${ }^{97}$ The entrances were blocked by pitfalls. When they were nevertheless discovered a fight occurred in which two agents were wounded. Several insurgents were killed or wounded.

In Mataru there was also a punitive expedition. The kampong Manet held out the longest, but on 24 August all the kampongs surrendered and the insurgents came and reported in Kalabahi. Here they received a sermon from Ogisaka: in fact all the insurgents deserved to be shot dead, but for this time it would be forgiven. The necessary threats followed, in case Mataru would cause future trouble.

It lasted took October before all the insurgents from Limbur had been herded together by the police and taken to Kalabahi. Of these, the following leaders were sentenced to prison terms: Maleiseni Senialuka of kampong Alukawati for 20 years (being sent to Kupang), the temukung of Bakudata, Lankafe Maifa, for 10 years, and the jimat sellers Lankafe Manilang and Padalawaë for life. With this, the interior troubles on Alor had come to an end. They had lasted from the beginning of 1942 to October 1943. The number of dead would not have been high. It is possible that the punitive expedition by the Japanese in 1942 cost more casualties among the

94 Quacksalver, provider of ostensibly powerful medical or supernatural stuff.

95 Civil administration unit.

96 Royal Netherlands Indies Army, Koninklijk Nederlands Indisch Leger.

97 River. 
population, but this is not likely. The people mostly kept hidden during such events. If the executions are included, the number of victims would not have exceeded fifty. Kapitan Limbur who caused the people so much trouble at the beginning, was replaced in 1944.

Kalabahi, 16 January 1946

The aspirant controleur J.R. Krol

Seen:

The commander of Alor

G.A.M. van Galen

The functioning controleur of Alor

For identical copy:

G.A.M. van Galen

\section{Copy.}

\section{General survey of the Onderafdeeling Alor over the period 3 to 22 November} 1945

On 3 November 1945 the Onderafdeeling Alor belonging to the Afdeeling Timor and Islands were once again brought under the rule of the Netherlands Indies Government. For this, the commander of the interior rule G.A.M. van Galen, captain of the reserve V.S.D. was brought over to Alor, onderafdeelingshoofdplaats Kalabahi, via an Australian corvette. ${ }^{98}$ This official was in March 1942 charged with the rule over this Onderafdeeling for 3 years. The functioning controleur of the interior rule Dimonti, captain of the reserve V.S.D. accompanied him; his mission was to visit the islands Adonara, Lomblen and Solor, belonging to the Onderafdeeling East Flores. Also, the payment master and the supply officer of Kupang accompanied him in order to assess the financial and economic situation of the place, and provide immediate report to the Conica ${ }^{99}$ in Kupang. In order to maintain peace and order a detachment of 50 Netherlands Indies troops were brought over under leadership of Sergeant-Major Houkes.

The Onderafdeeling Alor consists of 4 zelfbesturende landschappen. The foremost raja, the Raja of Alor, resides in Kalabahi. At the arrival in the roadstead of Kalabahi the Raja of Alor immediately reported on board the Australian corvette. After a brigade of militaries had disembarked, the writer went ashore accompanied by the other Nica officers and the Raja of Alor. There they were greeted with the anthem "The Wilhelmus"

98 After the Japanese capitulation, officially signed on 2 September 1945, the Allied command decided that Australia would occupy eastern Indonesia on behalf of the Allies (Farram 2003, p. 216). Therefore the Dutch officials arrived on an Australian corvette. Colonel Kaida Taitsuchi had signed the capitulation of the local Japanese forces at Kupang on 11 September.

99 Chief Commanding Officer of the Netherlands Indies Civil Administration. 
sung by the school children of Kalabahi. The reception by the population, also in particular the Chinese, was very good.

About 4 o'clock in the afternoon the Netherlands flag was hoisted at the government office. Present were the officers of the Australian corvette and an Australian officer of staff, the detachment of Netherlands Indies militaries, the Raja of Alor, the district chief of Dulolong and other native chiefs, the former government and landschap personnel, and a large part of the population of Kalabahi and surroundings. A short speech was delivered by the acting controleur Dimonti.

The zelfbestuurders of Kui, Batulolong and Kolana and the foremost chiefs were summoned to appear in Kalabahi. On 9 November, in the alun-alun ${ }^{100}$ of Kalabahi and in the presence of the zelfbestuurders of Alor, district chiefs, government and landschap personnel and a lot of people, the Netherlands flag was hoisted in a more solemn manner, followed by a lecture by General Blamey. ${ }^{101}$ The functioning controleur Dimonti then gave an address which was answered in turn by the Rajas of Kui and Alor. This was followed by religious services in the Protestant church and in the masjid. ${ }^{102}$

\section{Political situation}

The return of the Netherlands Indies government was in general greeted with joy by the zelfbestuurders, chiefs and population; especially so by the Chinese, who had to endure the hardest deprivations under the Japanese oppression. Especially during the last year the oppression exerted by the Japanese was heavy, since hundreds of coolies had to be sent to Timor Island even on a monthly basis, apart from those assigned to works on the islands Alor and Pantar. Especially the former [going to Timor] had to suffer a lot and mostly returned to their land in a miserable state. Many died from disease (dysentery) and by exhaustion, since no sufficient food was provided in many cases. Furthermore, people were required to sell a part of their harvest to the Japs.

The population had to suffer much from the often despotic behaviour of lesser Japanese militaries who were stationed at several places in the Onderafdeeling. The complaints by the people over this mistreatment should be investigated and reported. So far, 2 persons in Kalabahi, 7 in Kabir (Pantar island) and 3 in Blangmerang (Pantar Island) have succumbed as a consequence of mistreatment or been finished off by the Japs.

\section{Political associations}

Before the war there were various political associations among the Islamic part of the population (about 10,000 souls of the total number of people in the Onderafdeeling Alor, which is about 90,000), of which the P.S.I.I. had the largest following. During the first years of the Japanese occupation all political activity was prohibited. In December 1944 a new political association was formed at the request of the Japs, namely "Siap" (Serikat Islam Alor en Pantar), also called Persiapan.

100 Open place used for official gatherings etc.

101 I assume that this is the well-known Australian general Sir Thomas Blamey, although I have found no further information about his presence in these waters in the fall of 1945.

102 Mosque. 
This association had, apart from their attention to religious issues of the Islamic part of the population, as a goal the collaboration with the Japs for the aim of final victory, and in the end to achieve a "free" Indonesia under the umbrella of an Asia Raya Mulia"103 under the leadership of Japan. Many people joined this association more or less under the influence of fear of the Japs, others of free will, while some swore to fight along with the Japs to the last. After the Japanese had left in early September 1945, collaboration with the Japs was erased from the statutes of the association, and many wished to restrict the scope to the purely religious sector. Some left the association. A few voices suggested the complete abolition of the association, but at the suggestion of the young Raja of Alor, whose father-in-law was a leading figure in the association, it remained.

Preliminarily, one may not fear any important activities in terms of an Indonesian independence movement from this association. Certainly one needs to be on the alert about the possible arrival of propagandists from Celebes and Java.

\section{The attitude of the people towards the rajas}

In 1945 an uprising broke out in the mountain district Atimelang, landschap Alor, partly due to the vexations of Japanese militaries, and partly due to the improper behaviour of the Mohammedan kapitan of this district towards some chiefs. About the same time an old issue dating from 1918 was brought up in the mountain district Mataru, landschap Kui. That is, in 1918, namely, a mountain kampong was put to the torch by the military, at which occasion the Raja of Kui would have made a grand war booty consisting of moko (pusaka goods). This issue was increasingly brought up again. Due to the menacing attitude of the mountain people it was feared that Kalabahi would be ravaged. The rajas of Alor and Kui asked for assistance from the Japanese militaries in Kupang, help from whom was dispatched in the form of a police force. Five chiefs from the mountain district Atimelang were beheaded by the Japs, and order then returned. This action, however, has influenced the attitude of the mountain people of the districts Atimelang and Mataru towards their rajas in a disadvantageous way. A relapse of the resistance among this primitive population always remains plausible. However, when a sufficiently strong power apparatus is in place in Kalabahi, the primitive impact coming from this shall be enough to prevent an uprising.

\section{Economic situation}

The food situation in the Onderafdeeling is in general satisfactory, so that no particular measures about this were necessary, apart from a few kampongs in the landschap Kui. In the landschap Kui the harvest that had been collected for the Japanese was still present in the kampong storehouses. Since no payment for that had yet been handed over, it was in principle decided to hand back these provisions to the owners. The Raja of Kui will take the necessary measures for this.

103 Noble Greater Asia, an imagined Asian conglomerate that would be guided by Japan and oust the European colonial powers. 
On several places, further storage of rice for the Japs was found, in all about 35 tons, which is sufficient to purvey the Chinese, office staff, prisoners, and the leprosy home with foodstuff until the end of April 1946, the start of the new rice harvest. Information on how to achieve a proper distribution of these stores is being collected.

Before the war the population were still largely in the state of a household production economy. Money was practically only used for the payment of taxes. When one needed kain, etc. it was bartered with the Chinese merchants in exchange for goods. The population accepted the Japanese invasion money only insofar they needed it for the payment of taxes. The coastal population, office staff, etc. could only obtain the necessary foodstuff from the mountain people through bartering against goods (cloths, etc.). Probably there is therefore very little Japanese money in circulation among the indigenous population.

The new money that shall be circulated will in general be accepted and valued by the population only insofar that they can buy the necessary kain, etc. The possession of Japanese invasion money shall thus cause little disturbing influences on the trade of goods.

The officials will automatically gain possession of the new money through the payment of salaries, while the coolie population of Kalabahi and surroundings by their work will possess the necessary means for purchasing foodstuff. Only the Chinese part of the population will go through a difficult time since the trade is still almost shut down. Only some of them can help themselves to financial means, through involvement in the selling of goods from the Netherlands Indies in an export organization.

\section{Health situation}

The most frequent diseases among the people are malaria and framboesia. Since the supply of medicines was very poor under the Japs, and salversan ${ }^{104}$ injections were not administered, the state of health deteriorated. An application for medicines has already been submitted. It is highly desired that a physician is placed here.

\section{Agricultural information service}

In Kalabahi an agricultural inspector is present. The number of mantris is brought from 4 to 10 during the war. According to a report by the agricultural inspector there are, among the new mantris, 3 properly trained ones. Also out of political considerations, it is desired to keep these good resources, which has already been approved by the Conica.

\section{Popular education}

Popular education was in the hands of the Protestant mission before the war. This state of things is once again restored. Five new popular schools were opened during the war, while the number of learners at the other popular schools underwent a quite considerable expansion. In connection with this about 30 new teachers were employed, part of whom had only received very insufficient instruction. As far as possible these teachers should be kept. The expansion of po-

104 Or arsphenamine, a chemotherapeutic agent used to treat syphilis, sleeping sickness and other diseases. Due to dangerous side effects it was replaced by penicillin around the 1940s. 
pular education has in principle been approved by the Educational inspection, insofar that this expansion was not the consequence of forced measures by the Japs. These issues have already been dealt with in writing and orally.

\section{Mission}

In the Onderafdeeling 15 native teachers worked under the leadership of an Indian preacher; these were salaried by the government. The mission furthermore had in its service a number of guru agama and utusan injil. The popular teachers were mostly active as guru agama as well. The Japs discontinued the payment of salaries for these functionaries. Part of the persons remained with their tasks, supported by the Christian communities. Others found a way of living as popular educators. Others still withdrew to their kampongs. The native teachers have once again been established, enjoying their old income. The native teacher Francis in Kalabahi acts temporarily as the leader of the mission and the popular schools. The old state of things will be restored as quickly as possible.

Kupang 22 November 1945

The head of the Onderafdeeling Alor

G.A.M. van Galen

For identical copy:

The functioning controleur of Alor

G.A.M. van Galen

\section{References}

Barnes, Ruth, 2004, Ostindonesien im 20. Jahrhundert. Auf den Spuren der Sammlung Ernst Vatter. Frankfurt am Main: Museum der Weltkulturen.

Cribb, Robert, 2000, Historical atlas of Indonesia. Richmond: Curzon.

Cribb, Robert \& Brown, Colin, 1995, Modern Indonesia; A history since 1945. London \& New York: Longman.

Du Bois, Cora, 1944, The people of Alor; A social-psychological study of an East Indian island. Minneapolis: University of Minnesota Press.

Farram, Steven Glen, 2003, From 'Timor Koepang' to 'Timor NTT'; The political history of West Timor, 1901-1967, PhD Thesis, Northern Territory University.

Gonggrijp, G.F.E., 1934, Geïllustreerde encyclopaedie van Nederlandsch-Indië. Amsterdam \& Soerabaia: Graauw's.

Ricklefs, Merle C., 1981, A history of modern Indonesia, c. 1300 to the present. Houndsmill: Macmillan.

Widiyatmika, Munandjar, 2007, Lintasan sejarah bumi cendana. Kupang: Pusat Pengembangan Madrasah. 


\section{RAJAS OF ALOR}

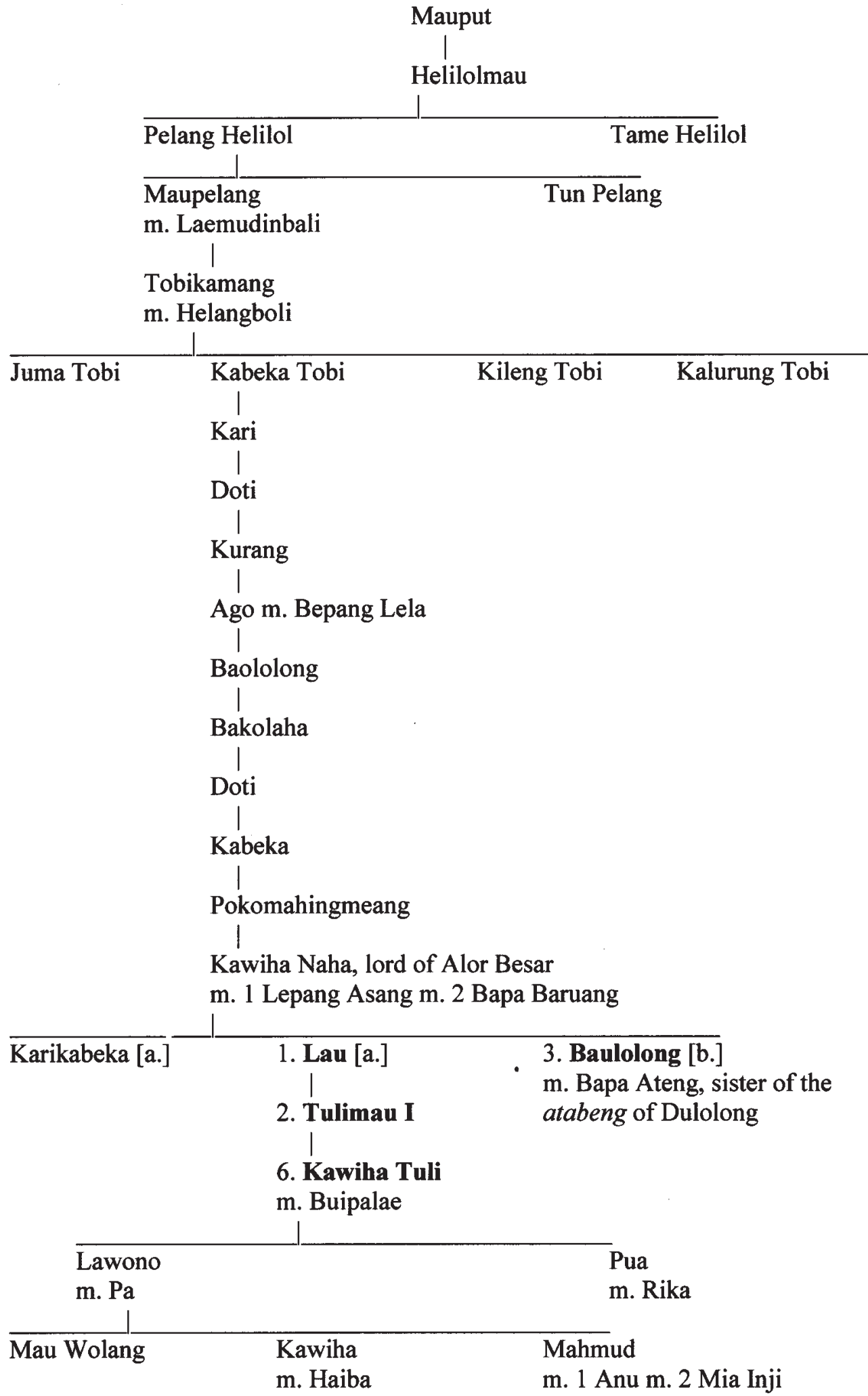




\section{Baulolong}

m. Bapa Ateng of Dulolong

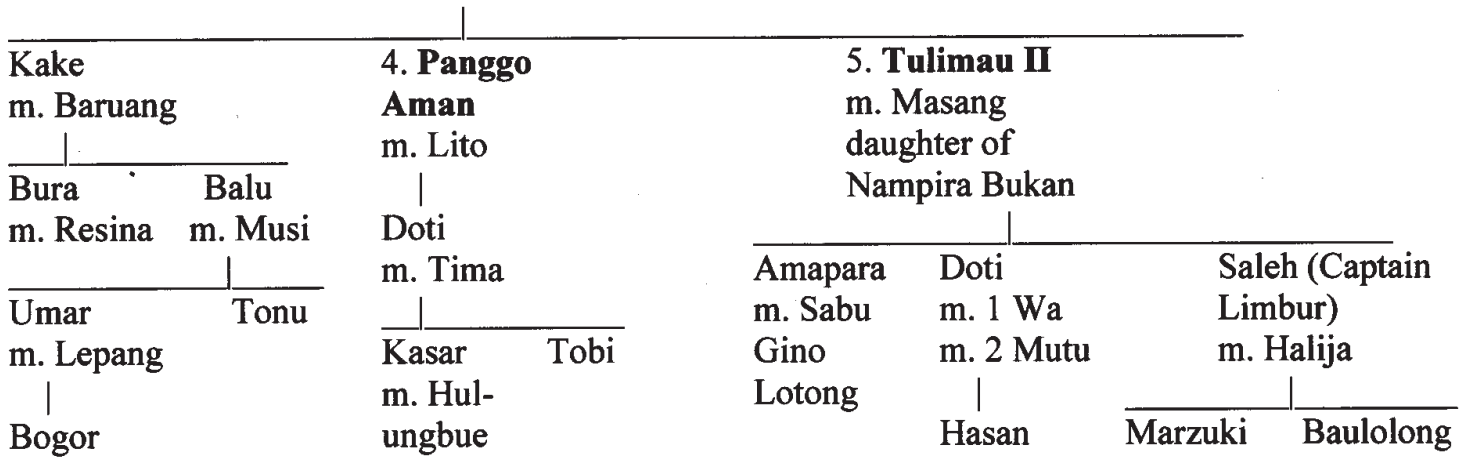

\section{THE DULOLONG LINE}

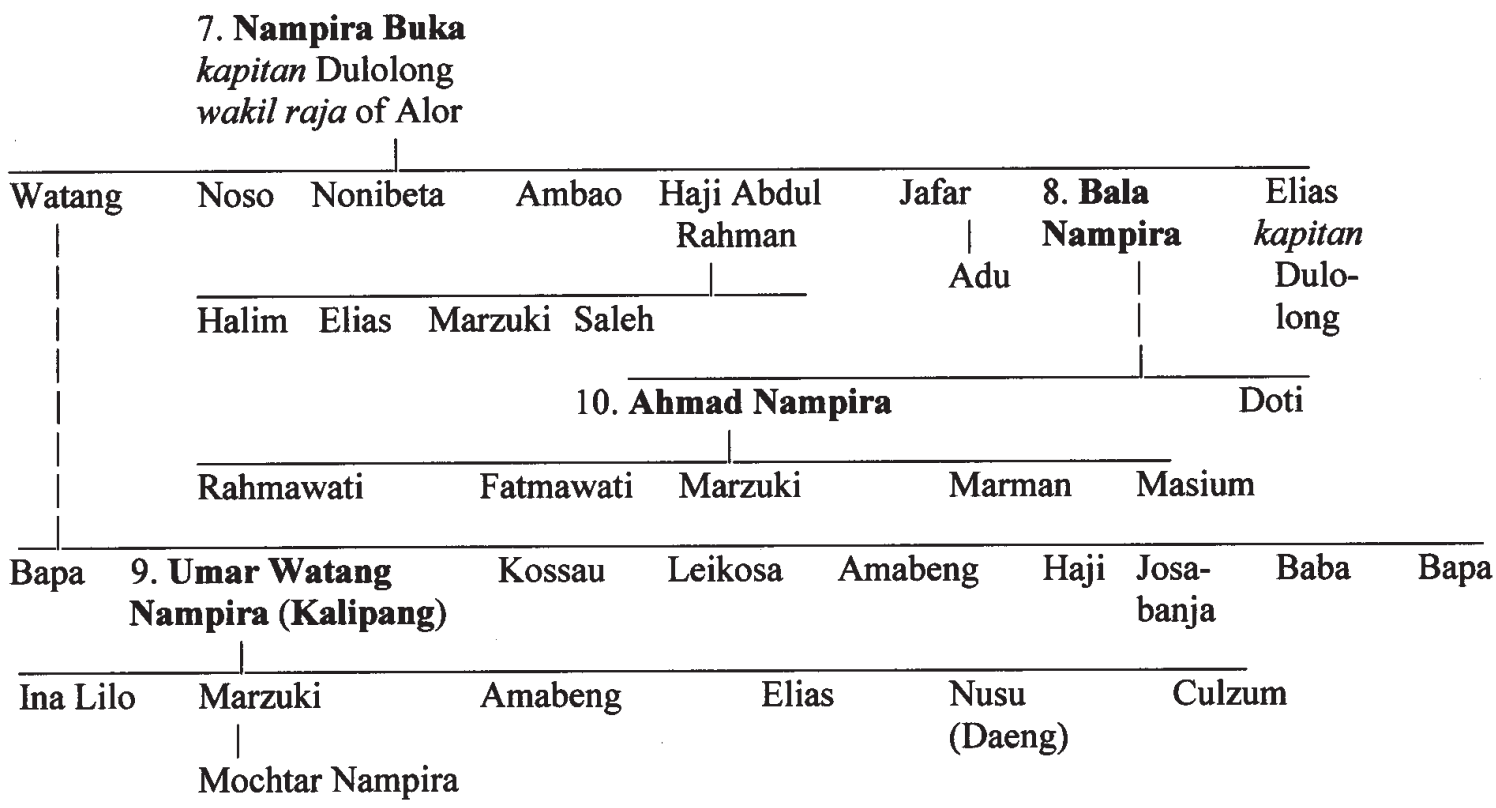




\section{RAJAS OF KUI}

Banla m. Kosla

Atamalei 1. Pasoma

m. Apankoli

m. Kamai

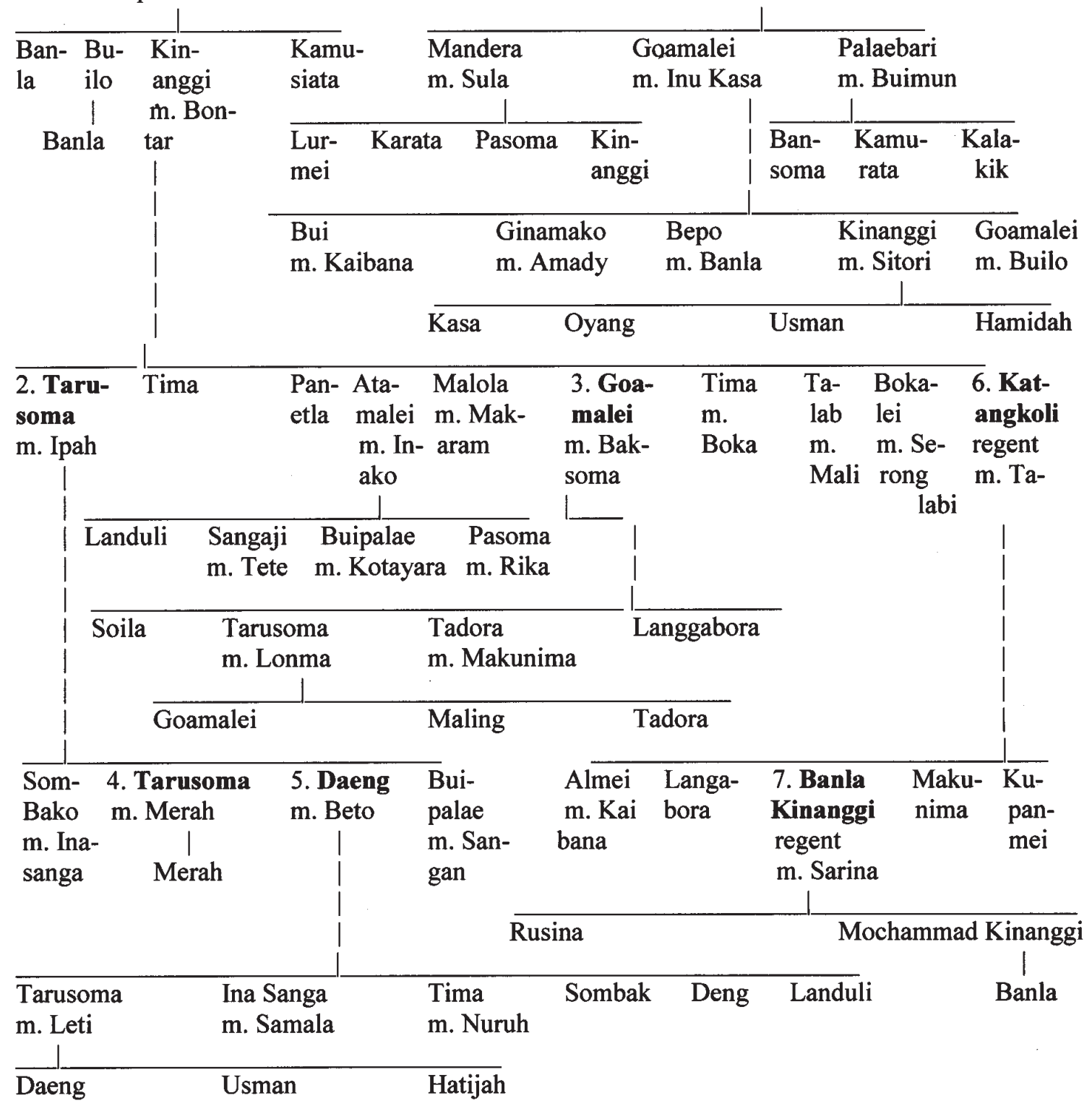

Genealogy of early Kui chiefs: Maleikili - Maleilok - Gawamalei - Atamalei - Maleilok Banla - Pasoma - Maleikili - Kinanggi - Maleilok - Pasoma - Gawamalei - Banla - Atamalei Gawamalei - Maleilok - Banla - Kinanggi - Banla - Pasoma - Atamalei - Maleikili - Atamalei - Pasoma - Kinanggi - Atsom - Pasoma- Kinanggi - Banla - Gawamalei - Banla - Pasoma [number 1 in the genealogy above]. 


\section{RAJAS OF PUREMAN}

Maulaka Sina

1. Sini Mau Laka

2. Tubul Sinimau

3. Sini Mau II

4. Tubulau I

5. Sini Mau III

6. Tubulau II

7. Sini Mau IV

8. Tubulau III

\begin{tabular}{ll}
\hline 9. Lapuimakuni & Makunimau \\
of Kolana
\end{tabular}

10. Tubulau IV

11. Painteri I

12. Resibera

13. Tubulau V

14. Painteri II

15. Malaikari I

16. Tubulau VI

17. Molana

8. Tubulau VII

19. Alobana

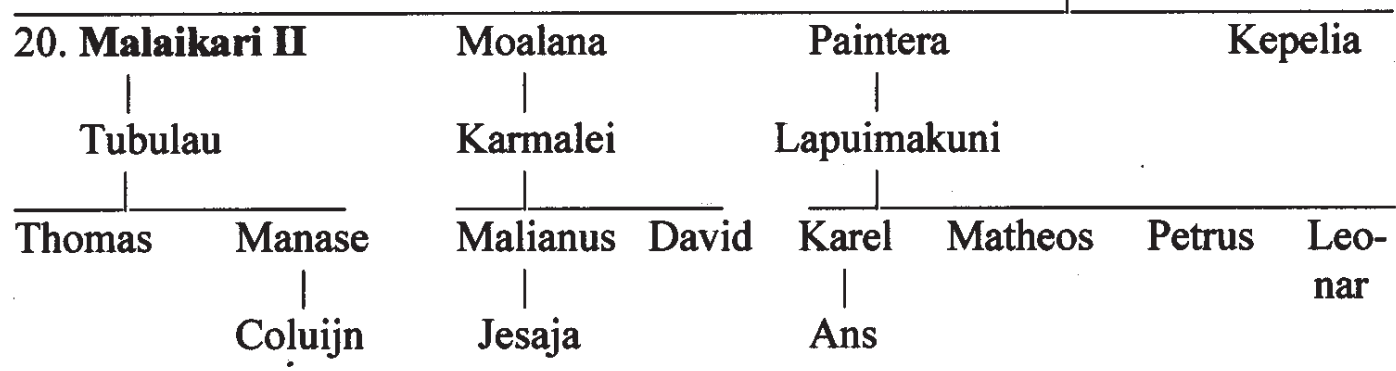




\title{
RAJAS OF KOLANA
}

\author{
Tubulau III of Pureman \\ 1. Makunimau I \\ 2. Takalamakunimau
}

3. Makuingtakalamakaing
4. Mautuka I




\title{
RAJAS OF BATULOLONG
}

\author{
1. Karimalei Gapada \\ m. 1 Lapalai \\ m. 2 Siladeng \\ m. 3 Talseran
}

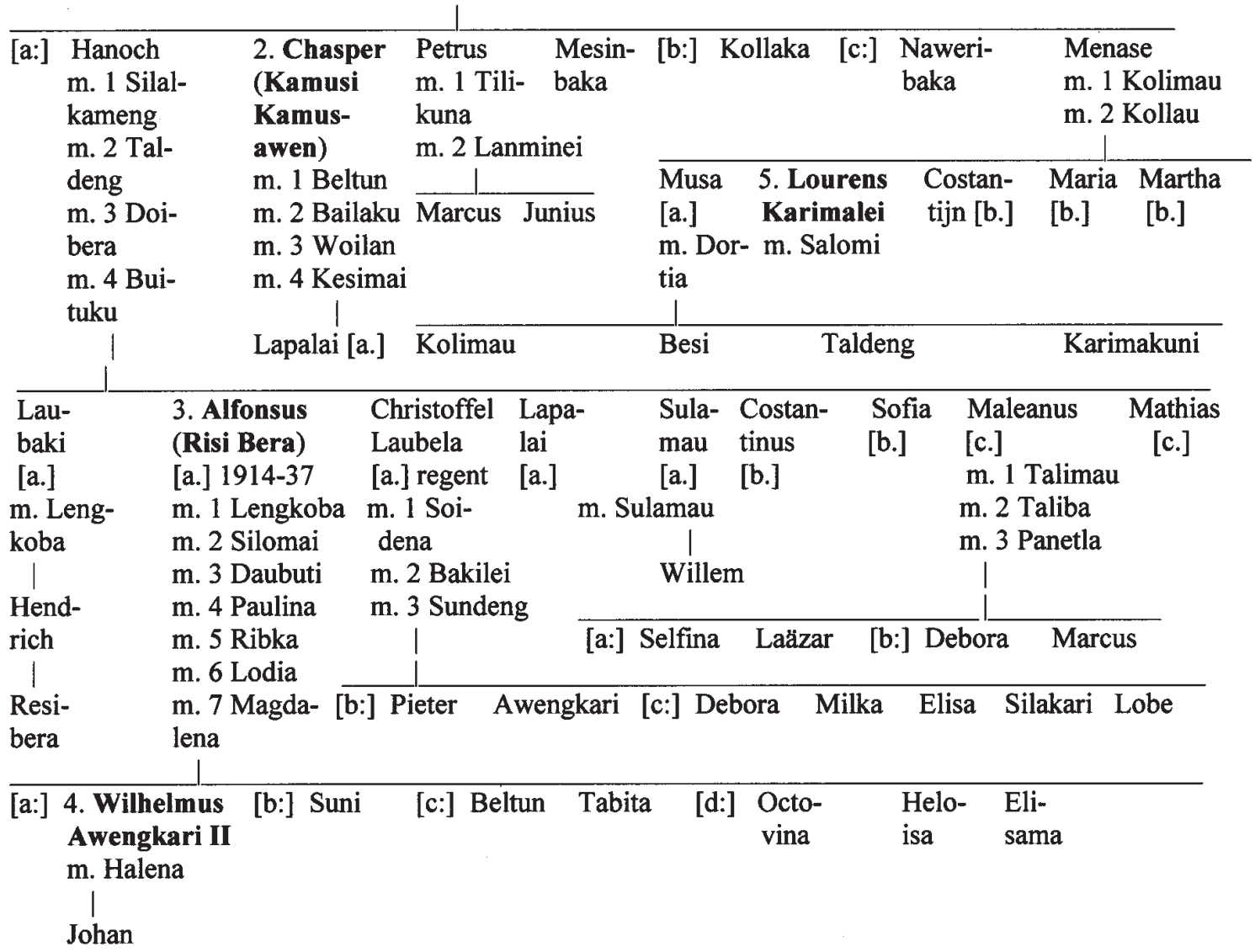

